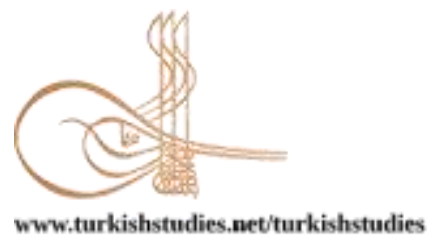

Turkish Studies

\title{
Ayasofya I. Mahmûd Kütüphanesi Çini Bezemeleri Üzerine Bir İnceleme
}

\author{
An Examination of Hagia Sophia Mahmud I Library Tile Revetments
}

\author{
Zehra Dumlupınar*
}

\begin{abstract}
:
"Neither the high society nor the commons have seen such a decorated post

With all bezels, sealed to witness, on the walls." (Dağl1,1948: 60; Ünsal 2011: 205)

Hagia Sophia, the topic of legends, witnessing numerous historical events as the most important religious center in Byzantium, has undoubtfully survived in its rightful reputation with the Turkish and Muslim identity adorned after the conquest. During Sultan Mahmud I's period, one of the architectural works added in Hagia Sophia to contribute to make it a complex is the Library of Hagia Sophia. The architecture, decoration and the donated books of the Hagia Sophia Library which has enthusiastically resonated both the state officials and the public due to its privileged status and beauty during the period it was built are individually important. The Library of Hagia Sophia, placed between two supports on the southern nave of Hagia Sophia in 1739, consists of three sections including the reading hall, the corridor, and the books treasury. The Library, which has undergone many reparations over the years, lastly received a major renovation in 2014. Today, the Reading Hall, decorated with lounges, carpets, and valuable woodcrafts, sticks out with its tile inscriptions, glamorizing the walls halfway, and additional tiles. The walls in the corridor connecting the Reading Hall to the Books Treasury is tiled top to bottom. On the walls decorated with mixed tiles of various periods, valuable $16^{\text {th }}$ century Nicaean panels and the tiled epigraph line attract attention. Still, the most elaborate hall in the library is the Books Treasury, home to the wood bookcase and the valuable handwritten manuscripts on the alcoves in the walls. The Books Treasury, consisting of adjacent two sections with domes and vaults, resembles a jewelry box, with tiles decorating its walls top to bottom, in the Hagia Sophia. This article examines the tile decorations found in all sections of the library. The library floor plan used in this article was obtained from "The Project of Ceramics Conservation and Renovation in the Hagia Sophia Museum, Mahmud I Library, by the Istanbul Restoration and Conservation Directorate of Central and Area Laboratory". The alphabetical nomenclature of the location walls on the floor plan is adopted in this study also. Library tiles include epigraphs, panels, connection tiles, windowsills, borders, and plinths of various periods and production centers.
\end{abstract}

Structured Abstract: Hagia Sophia, the most important religious center in Byzantium, has survived in its rightful reputation with the Turkish and Muslim identity adorned through addition of the library, primary

\footnotetext{
* Dr. Araştırma Görevlisi, Marmara Üniveristesi İlahiyat Fakültesi İslam Tarihi ve Sanatları Bölümü Research Assistant Dr. Marmara University, Faculty of Theology, Islamic History and Arts Department ORCID 0000-0002-8145-7082

dumlupinarzehra@gmail.com

Cite as/ Atıf: Dumlupınar, Z. (2020). Ayasofya I. Mahmûd Kütüphanesi çini bezemeleri üzerine bir inceleme. Turkish Studies, 15(3), 1783-1807. https://dx.doi.org/10.29228/TurkishStudies.42240

Received/Geliş: 23 March/Mart 2020

Accepted/Kabul: 20 June/Haziran 2020

Copyright $($ ) MDE, Turkey
} 
school, sultan's pavilion, foodbank, and the fountain during Sultan Mahmud I's period (ruling H. 1143-1168 / 1730-1754 common era) to make it a classical Ottoman complex. This article examines the Library, located in the interior of the Hagia Sophia, and its ceramics, dated to various periods. The opening ceremony for the Library, set between two supports on the southern nave of the Hagia Sophia, was held, a few months after its construction was completed, on H. 24 Muharram 1153 / 21 April 1740 common era, in Sultan's presence. The Mahmud I Library of Hagia Sophia, which was enthusiastically received both by the state officials and the ordinary people and standing out with its privileged status based on its location and beauty in Hagia Sophia among other library buildings, consisted of valuable handwritten manuscripts donated by the Treasury, prominent state officials, and the people. Here, the educational services offered in the library buildings were systematized and professors as well as the students attending classes received payments (Erünsal, 1991: 213). Some of the books found in the library were transferred to the Turkish and Islamic Arts Museum in 1916. The Library, which was rendered dysfunctional upon the transfer of the remaining 5086 tomes to Suleymaniye Library in 1968, shares almost the same fate as the Hagia Sophia's. The latest major renovation in the library, which had undergone many reparations since $19^{\text {th }}$ century, took place in 2014.

The Hagia Sophia Library consists of the Reading Hall, the Books Treasury, and an L-shaped corridor linking those two sections. Tile covers found on all walls of the library sections are not contemporaneous with this structure; they were produced earlier or later and placed on the library walls at different times. Majority of those ceramics are of $16^{\text {th }}$-century Nicaea tiles. Akar states that some of the ceramic covers, transferred from the palace ceramics treasury based on Sultan's orders, have not lasted to this day. Based on "The Project of Detecting Imitation Ceramics and Tiles Replaced with the Original Ceramics and Tiles during Earlier Renovations in the Hagia Sophia Museum, Mahmud I Library" by the Istanbul Restoration and Conservation Directorate of Central and Area Laboratory, panels with cypresses replaced with the originals found in the entrance of the Books Treasury, during 1882-1896 renovations, have the name of Choisleroi Seine workshop, a French production, printed on the back surfaces. In the Library, tiles made in the Istanbul Tekfur Palace during Ahmed III's period (1703-1730) and also some yellow-colored European ceramics, other than the Nicaean tiles, were used.

In this study, the Library ceramics were classified under the following groups based on design basics: 1 . Panels in rectangular fields, specifically designed for their location, with a pattern beginning with a bottom-up detail completed at upper levels; 2 . Connection tiles, available to produce as many as necessary by lifting or folding on all four or two sides, designed on one or four squares; 3. Borders, enclosing panels, connection tiles, windows, and case niches, that could be added as needed on both ends; 4. Corner fillings decorating the triangle corners of windows; 5. Plinth tiles, used on the lowest levels in interior spaces, that could be continuously added on both ends. Epigraph tiles and cinctures are also found.

In the Hagia Sophia Mahmud I Library, there are, totally, three original $16^{\text {th }}$-century Nicaean panels of which two are located in the corridor and one is in the Books Treasury. These panels were designed symmetrically and decorated with semi-styled Hatayi details mostly in cobalt blue, coralline, and turquoise as characteristic colors of the period. Spring tree and semi-styled flower patterns, the most beloved among $16^{\text {th }}$ and $17^{\text {th }}$ century details, were frequently used in Ottoman religious and civic structures. On those panels, spring tree or branches, stemming from the bottom, move up with decorated large and small spring flowers. Various semi-styled flowers are used in the lower levels of the compositions; şemse motives and vases are also frequently found. Şemse motives and vases are not found on the panel of spring trees in the Library corridor. Rumi motives were used on the corner fillings. The Hatayi-patterned panel in the corridor features an arch on top, corner gussets, and a framing border. With semi-details placed on sides, it is a connection panel, progressive on both ends. Such connection panels were often preferred in the next, $17^{\text {th }}$ century. A typical $16^{\text {th }}$-century panel is the Hatayi-patterned symmetrical panel found in the Books Treasury. The marvelous vase with Rumi decorations in the bottom, the belly of leaves in the middle, and its detailed motives point out the period it was made (Photo 22-23).

Among the connection ceramics used in all sections of the Library, those dated to $16^{\text {th }}$ century, are those that were used in Ottoman structures. They include connection ceramics that were designed within the half of a tile square to progress, tiles that were designed on one square to progress on four ends or the ones that were designed in four squares to progress on all ends. Connection tiles used for decoration on large areas such as walls, arch surfaces, ceilings, elephant-foots, with the semi-motives left on ends within the area of design, provide continuous progression. As can be known, the ceramics factory built in Istanbul Tekfur 
Palace during Ahmed III's period had a short-lived manufacturing term. Ceramics of this period are known with pale blue background colors and details drawn as spiky ends. The most popular detail in ceramics of this period may be the spots and the tiger-line forms. In addition to the spot-patterned tiles used on D Wall in the Reading Hall, in the Corridor, and other necessary spaces in the Books Treasury, Tekfur Palace ceramics with various designs were also used in windowsills and alcoves for books. These tiles feature patterns of hyacinth, bunches of flowers, and penç (Photo 29-31). Slight abrasion is found on the surfaces of tiles, dense in cobalt blue, crimson, and petrol green on pale blue background. In the Library, imitation connection ceramics replacing the originals are located in the Reading Hall, Corridor, and the Books Treasury, also.

Border tiles, surrounding and lining panels, connection tiles with similar patterns, windows, and alcoves for books, posing as frames, are similar to the connection ceramics in that they provide progression on both ends. In the Books Treasury, tiles with patterns of bunch of grapes and vine leaves stand out among the $16^{\text {th }}$ century border tiles. (Photo 33). Border tiles, produced in Tekfur Palace and imitation border tiles were used in all sections of the building (Photos 35,36-38).

In the Books Treasury, triangle gussets on the top windows are randomly decorated with semi-styled flowers. Gussets, decorated with various flowers including mainly roses, tulips, and clovers, feature the classical $16^{\text {th }}$-century colors. On no. 2 window on C Wall, cloud patterns, in contrast to the others, were used. The patterns were colored white on coralline background on gussets, used on both ends, providing progression through semi-completed patterns.

Imitation plinth tiles, symmetrically decorated with semi-styled flowers, were used on two walls in the Books Treasury, the most elegantly designed room of the Library.

Tile inscriptions, used for decoration on interior and exterior spaces in religious and public buildings in all periods, attract attention also with the content of their texts. Particularly in $17^{\text {th }}$ century, the use of Celi Thuluth calligraphy, colored in white on cobalt blue background, with details occasionally filling the empty spaces in the between, became more frequent. Tile inscriptions, found as panels on the calligraphy tiles circulating the entire hall, some spaces on the walls or on window-tops, were used in the Reading Hall and Corridor section in the Hagia Sophia Mahmud I Library. The Books Treasury, on the other hand, is quite rich in epigraphs; however, calligraphy on tile materials is not found here. Verses, Holy Names, and prayers are inscribed on epigraphs used as calligraphy tiles in the Reading Hall and the Corridor. Epigraphs are not signed and dated.

The Library, added in the Hagia Sophia in 1739 during Sultan Mahmud I's period, is indeed located between two supports on the southern nave in the sanctuary. The Library, well received by all walks of life during the period it was constructed, is the topic of this article, through its tiles consisting of a part of its decoration. The Library walls, with mainly the $16^{\text {th }}$ century Nicaean tiles, ceramics of later periods, and imitation tiles replacing originals in renovations, constitute an important link in the History of Tiles Arts.

Keywords: History of Art, Hagia Sophia, Mahmud I, library, tiles.

Öz:

\section{"Öyle bir ziynetli makām}

Görmemiştir hās u âm

Cümle duvarları kâş̧̂े

Tuğra-yl şâhîde nizâm. “ (Dă̆ll,1948: 60; Ünsal 2011: 205)

Bizans'ın en önemli dini merkezi olarak sayısız tarihî vak'aya şahitlik eden ve efsanelere konu olan Ayasofya, şüphesiz fetihten sonra da büründüğü Türk ve Müslüman kimliğiyle haklı şöhretini devam ettirerek günümüze kadar ulaşmıştır. Sultan I. Mahmud zamanında Ayasofya'ya eklenerek onun bir külliyeye dönüşmesine katkı sağlayan mimarî eserlerden biri de Ayasofya Kütüphanesi'dir. Yapıldığı dönemde ayrıcalıklı konumu ve güzelliğiyle hem devlet ricâli hem de halk arasında büyük yankı uyandıran Ayasofya Kütüphanesi, mimarîsi, tezyinâtı ve vakfedilen kitapları bakımından ayrı ayrı önem arzetmektedir. 1739 yılında Ayasofya'nın güney nefi üzerinde, iki payanda arasına konumlanan Ayasofya Kütüphanesi, Okuma Odası, Koridor ve Hazîne-i kütüb olmak üzere üç bölümden meydana gelir. Kütüphane’nin bir kısmı mabede 
bitişiktir, bir kısmı ise mabedin dışında kalır. Yıllar içerisinde pek çok restorasyon geçiren Kütüphane'nin son esaslı onarımı 2014 senesinde tamamlanmıştır. Günümüzde, sedir, halı ve kıymetli ahşap eşyalarla tefriş edilmiş olan Okuma Odası yarı duvarlarını bezeyen çini kitabeleri ve ulama çinileriyle ön plana çıkmaktadır. Okuma Odası'nı Hazine-i kütübe bağlayan koridorun duvarları baştan aşağı çinilerle kaplıdır. Farklı dönemlere ait çinilerle karışık bir şekilde dekore edilen duvarlarda kıymetli 16. yüzyıl İznik panoları ve çini yazı şeridi dikkati çekmektedir. Yine de Kütüphane'nin en özenilmiş odası, kitabeleri, ahşap kitap dolabı ve zamanında dolap ve nişler içerisinde kıymetli el yazması eserlerin bulunduğu Hazine-i kütüb'dür. Kubbeli ve tonozlu yan yana iki kısımdan oluşan Kitap hazinesi, duvarlarını baştan aşağı bezeyen çinileri ile Ayasofya'nın içinde bir mücevher kutusunu andırır. Bu makalede, kütüphanenin tüm bölümlerinde yer alan çini bezemeler üzerinde durulacaktır. Fotoğraflar 2018 yılında kütüphaneye yaptığım ziyaretlerde tarafımdan çekilmiştir. Kütüphane planı ise "İstanbul Restorasyon ve Konservasyon Merkez ve Bölge Laboratuarı Müdürlüğü, Ayasofya Müzesi I. Mahmud Kütüphanesi Çini Koruma Onarımı Projesi”nden temin edilmiştir. Plan üzerindeki mekan duvarlarının harf sistemine göre adlandırılması bu makalede de esas alınmıştır. Kütüphanenin çinileri, farklı devir ve üretim yerlerine ait olan kitâbeler, panolar, ulama çiniler, pencere köşelikleri, bordürler ile süpürgelik çinileri olarak tasnif edilerek değerlendirilmiştir.

Anahtar Kelimeler: Sanat Tarihi, Ayasofya, I. Mahmud, kütüphane, çini.

\section{Giriş}

532-537 yılları arasında İmparator Justiniaus (sal.527-565) tarafından inşa edilen Ayasofya 1453 'te İstanbul'un fethine kadar Bizans'ın en önemli ibadethanesiydi. Fetihle birlikte kiliseden camiye tebdil edilen mabed, yüzyıllar içerisinde Osmanlılar'ın yaptırdığı yerinde onarımlar, gösterdikleri büyük ihtimam ve onu Türk ve Müslüman çehreye büründüren mimari ve dekoratif eklentilerle günümüze kadar ulaşmıştır. Tursun Bey, Târîh-i Ebü'l-Feth'de "Ve ol bir binâ-yı metîn ve bünyân-ı hasindür ki, hadd-i vaz'ına nazar, felek-misâl tetarruk-ı ihtilâl vehminden hâlî olması vâcib ve nazîri mümten̂̀', 'lem yuhlak mislühâ fi'l-bilâd' (Kur'an-ı Kerîm 89/8) dinilmelü, ammâ sıfat-ı hudusî îcâbından, mürûr-ı dühûr ile tevâbi' ü levâhıkı hāne-i hasûd-ı devletmendân gibi harâba varmış, ve anun rahnesine taş kor mi'mâr, dâyire-i pergâr-ı imkânda vücûdı kalmamış, hemân andan bir kubbe kalmış." diyerek fethin sonrasında Ayasofya'nın harap vaziyetini tasvir etmektedir. (Tursun Bey, 1977: 63-64) İnşâ edildiği zamandan bu yana adı İstanbul ile birlikte anılan Ayasofya geçmişte olduğu gibi günümüzde de yerli ve yabancı seyyah ve araştırmacıların ilgisini çekmeye devam ediyor. Fetihten itibaren 1923 yılına kadar cami olarak kullanılan Ayasofya, I. Mahmud (sal. H.1143-1168 / M.1730-1754) zamanında 1739-1743 yılları arasında yapıya eklenen kütüphane, sıbyan mektebi, hünkâr kasrı, imâret ve şadırvan ile bir Osmanlı kompleksine dönüşmüştür. (Eyice, 1991: 2) Mabed, 1934 y1lında müzeye çevrilmiştir.

I. Mahmud Ayasofya'dan başka Fatih ve Süleymaniye Camiileri'nde ve Galata Sarayı'nda; ayrıca Vidin ve Belgrad'da kütüphaneler yaptırarak buralara değerli el yazması eserler vakfetmiştir. Topkapı Sarayı Enderun Kütüphanesi yine onun vakfettiği kitaplar ile zenginleşmiştir. I. Mahmud'un kütüphane inşasına önem vermesi dönemin devlet adamlarına da ilham olmuş, İstanbul onun devrinde kütüphanelerle bezenmiştir. Necip Asım, Sultan I. Mahmud'un bu sebeple "sultân-ı muhibbân-ı kütüp" ünvânını almaya kesb-i istihkāk ettiğini söyler. (Necip Asım, 2012: 125) Siyasi başarılarının yanı sıra mimarlık faaliyetleri ile ön plana çıkan I. Mahmud çağdaş araştırmacılar tarafindan muammir-i bilâd olarak isimlendirilmiştir. ${ }^{1}$

Ayasofya'nın güney nefi üzerinde yer alan I. Mahmud Kütüphanesi H.1152 / M.1739-1740 senesinde inşa edilmiştir. Açılış merasimi Kütüphane'nin vakfiyesinin hazırlanmasından birkaç ay sonra 24 Muharrem 1153'de gerçekleşmiştir. Kütüphane'nin bakımı için Cağaloğlu Çifte Hamamı ile Anadolu ve Rumeli'de geniş araziler vakfedilmiştir. (Eyice, 1991: 214) Kütüphane Hazine-i

\footnotetext{
${ }^{1}$ I. Mahmud döneminde inşa edilen kütüphane binaları ve dönemin diğer mimari faaliyetleri hakkında detaylı bir araştırma için bkz. Şahin, 2009: 113-140.
} 
Âmire ile önemli devlet adamlarının vakfettiği kitaplardan oluşuyordu. ${ }^{2}$ Diğer Osmanlı kütüphanelerine kıyasla sayıca daha çok görevlinin çalıştığı Ayasofya Kütüphanesi'nde görevlilere verilen ücret miktarı da daha fazlaydı. (Erünsal, 1991: 213) Kütüphane içindeki eğitim hizmetleri burada düzenli hâle getirilmiş, hocaların yanı sıra derslere devam eden talebelere de ödenek tahsis edilmişti. (Erünsal, 1991: 213) Kütüphane'de bulunan kitapların bir bölümü 1916 yılında Türkİslam Eserleri Müzesi'ne aktarılmış, geri kalan 5086 cilt ise 1968'de Süleymaniye Kütüphanesi'ne taşınmıştır.

Ayasofya I. Mahmud Kütüphanesi yapıldığı dönemden bu yana pek çok onarım geçirmiştir. 1738-1739 yıllarında Ayasofya Camii'nde yapılan onarımlarda Kütüphane için sekiz adet müşebbek mükemmel dervâze ve bir adet dershane kapısı sipariş edilmiştir. (Akgündüz ve Baş, 2005: 424.) Topkapı Sarayı Müzesi Arşivi'nde yer alan 1739 tarihli bir defterde Kütüphane ve dershaneler için gerekli olan inşaat malzemelerinin bir listesi ve ücret dökümü yer alırken, I. Abdülhamid döneminde, 1777 yılında Kütüphane ve İmaret'in onarımları için 4920 kuruşluk harcama yapıldığı kaydedilmektedir. Sultan Abdülmecid devrinde Ayasofya'da yapılan en geniş kapsamlı ve bütçeli onarımlar gerçekleştirilir. 1847- 1851 yılları arasında cereyan eden onarımları yürütme görevi Mimar G. T. Fossati'ye verilmiştir. Ayasofya Camii ile birlikte külliyenin diğer birimlerini de kapsayan onarımlarda kütüphane ve medresenin tamiratı ve türbenin çatısı için gerekli olan meblağ 1850 tarihli Tezkire-i Sâmiye'de geçerken, II. Abdülhamid devrine ait bir diğer vesikada Kütüphane ve II. Selim ile III. Murad türbeleri çinilerinin tamiratı ile ilgili olarak hesaplanan yekûnun Evkaf-1 Hümayun bütçesinden karşılanacağı belirtilir. 1896 tarihli bir diğer belge ise tamiratın detaylarına yer vermeyerek Kütüphane, cami ve türbelerde gerçekleştirilecek onarımlar için gerekli meblağ 1 ve sadrazam tarafından padişaha arzedilen izin talebi ve talebin kabulünü içerir. Cumhuriyet dönemine ait 1960 tarihli bir yazışma ise Kütüphane'nin kitapları ve kitap dolaplarının tamiratına ilişkindir. (Diker, 2010: 61, 64, 83, 90, 100, 130). 1981 yılında Mimar Hüsrev Tayla yönetiminde Taç Vakfı tarafından gerçekleştirilen restorasyonda, kubbe kurşunlarından sızan sular sebebiyle kabaran çinilerin konservasyonunun yapılarak sağlamlaştırıldığı söylenmektedir. (Tayla, 1986: 13) Son olarak 2012-2014 yılları arasında gerçekleşen restorasyonlarda Kütüphane'nin bütün bölümlerinde yapılan onarımlar detaylı bir şekilde rapor edilmiştir. Bu raporlarda çinilerin orijinal ve imitasyon olanları tespit edilmiş, bütün çini karoların sayısı ve ölçüleri belirtilmiş, çinili duvarların çizimleri yapılmıştır. Çini yüzeyleri temizlenmiş, arkalarında boşluk olan duvar yüzeyleri harçla düzleştirilmiş, yerlerinden çıkarılan çiniler tekrar yerlerine tatbik edilip derzler doldurulmuştur. (Çini Koruma Onarımı Uygulama Raporu, 2012: 1-57.)

\footnotetext{
${ }^{2}$ Kütüphaneye vakfedilen kitapların isimleri, vâkıflar ve Osmanlılar zamanında hazırlanan fihristleri hakkında detaylı bilgi için bkz. Malkoç, 1956: 11-12; 1957: 29-33.
} 


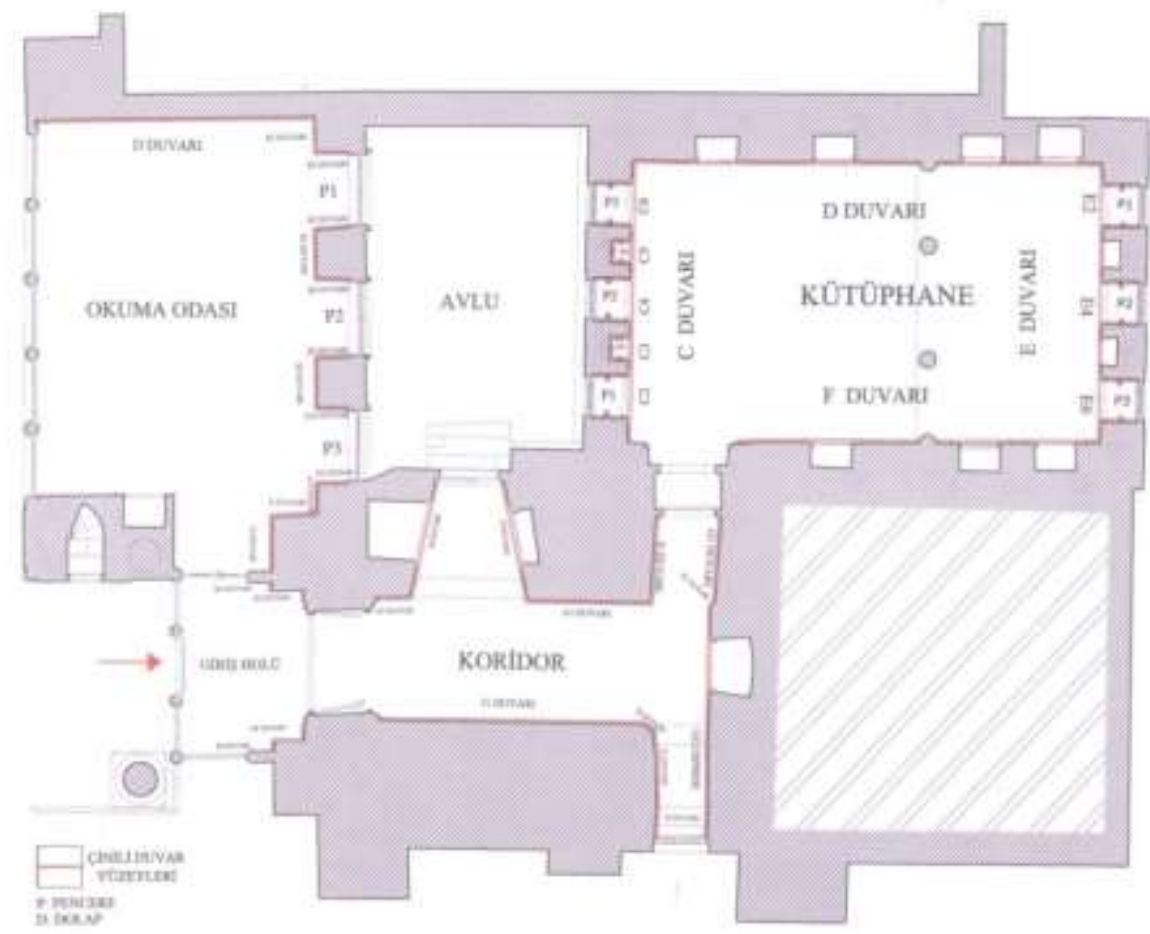

1: Ayasofya I. Mahmûd Kütüphanesi Plan1. (Istanbul Restorasyon ve Konservasyon Merkez ve Bölge Laboratuarı Müdürlügü, Ayasofya Müzesi I. Mahmud Kütüphanesi Çini Koruma Onarımı Projesi, 20122013: 1)

\section{Ayasofya Kütüphanesi’nin Mimarî Özellikleri ve Çini Bezemeleri}

\subsection{Okuma Odası}

Ayasofya'nın güney nefi üzerinde iki payanda arasında konumlanan kütüphane binası Ayasofya hariminden Türk baroğu tarzındaki altın varaklı pirinç şebekeler ile ayrılır. Kitâbelerinde sülüs yazıyla esma-i hüsnâ yazılı olan pano halindeki şebekelerin arasında baklava dilimi başlıkları olan mermer sütunlar yer alır. Giriş kapısının yâ Fettâh yazılı tokmakları meşhurdur. Kapıdan girince solda, Okuma Odası olarak bilinen ilk mekan da Ayasofya harimine bu müşebbek duvarın arkasindan bakar. 


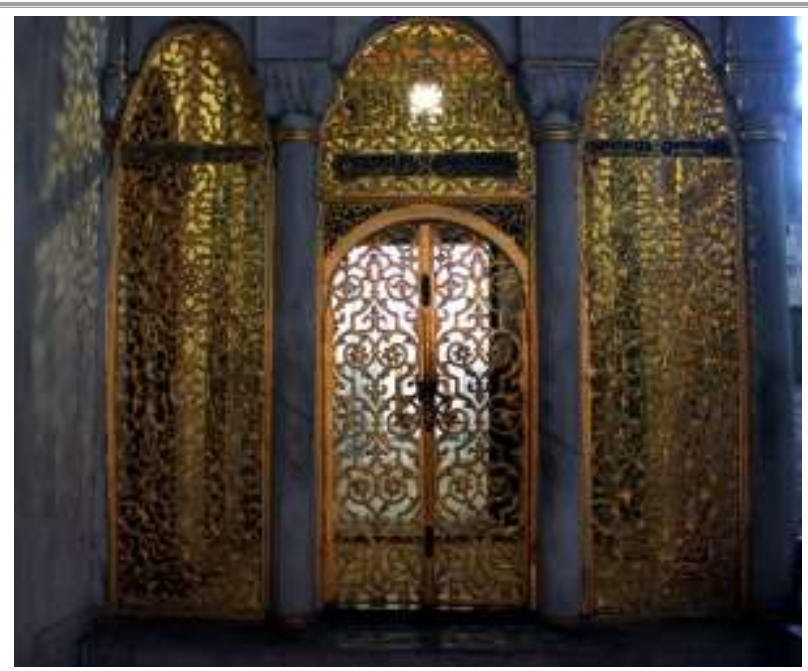

2: Kütüphane girişi.

Okuma Odası, dikdörtgen planlı ve düz ahşap tavanlıdır. Ahşap parkelerinin üzeri günümüzde halı ile kaplanmıştır. Ayasofya taşlığına bakan üç penceresi bulunur. Okuma Odası'nda sedef ve bağa kakmalı iki adet ahşap Kur'an mahfazası, biri kitâbeli olmak üzere beş adet rahle, iki adet okuma sehpası; giriş yönünde ahşap üzerine fildişi kakma kapakları olan bir dolap ile ahşap kasalı bir duvar saati bulunur. Okuma Odası'nda pencere araları ile iki duvarının yarıdan yukarısı çinilerle kaplıdır. Bunlar çok renkli sıraltı tekniğinde çini kitâbeler, ulama kompozisyonlu çiniler ve bunların etrafını çeviren bordür çinileridir.

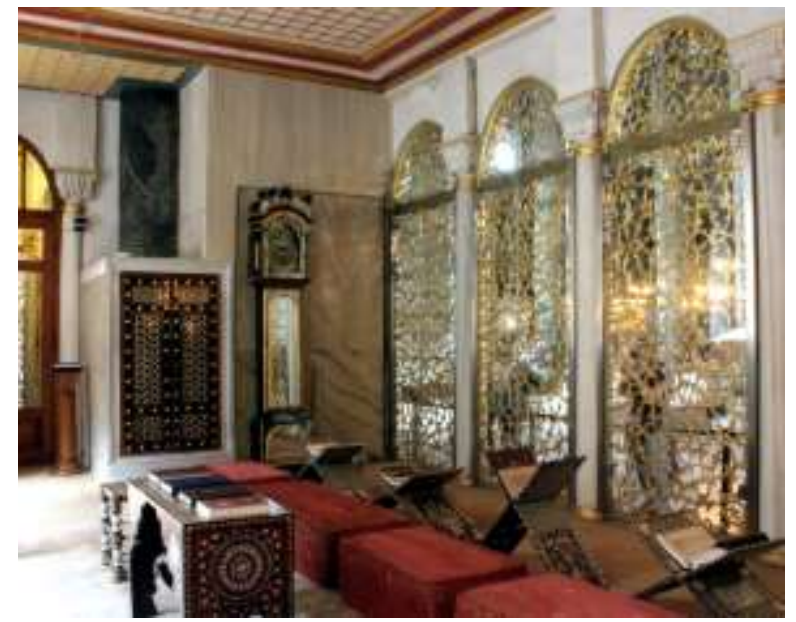

3: Okuma Odası'nda ahşap eserler.

Ayasofya I. Mahmud Kütüphanesi Okuma Odası'nda iki adet çini kitâbe yer alır. Giriş kapısının karşısındaki duvarda (D Duvarı), duvarın üst kısmını tek satır hâlinde ve boylu boyunca kaplayan, 12 adet tam kare ve 12 adet dikdörtgen olmak üzere toplam 24 parçadan oluşan kitâbede lacivert zemin üzerine beyazla ve celî sülüs ile: "Bismillahirrahmânirrahîm. Hüvallâhü'l-lezî lâ ilâhe illâ Hû. er-Rahmân er-Rahîm el-Melik el-Kuddûs es-Selâm el-Mü'min el-Müheymin el-Azîz el-Cebbâr el-Mütekebbir el-Hāllk el-Bârî el-Musavvir el-Gaffâr el-Kahhâr el-Vehhâb er-Rezzâk elFettâh el- 'Alîm el-Kābıd." yazılıdır. Yazı boşluklarında herhangi bir motif kullanılmamıştır. İkinci çini kitâbe ise aynı duvarda, diğerinin hemen altına yerleştirilmiştir. Etrafı tek sıra bordürle çevrili olan kitabe 16 adet çini karodan oluşur. Kitâbede lacivert zemin üzerine beyazla ve celî sülüs ile 
"Lâ ilâhe Illlallah" yazılıdır. Yazı zemininde, Muhammed kelimesinin üstünde iki adet gül motifi yapraklarıyla beraber yer alır. (Fotoğraf 4)

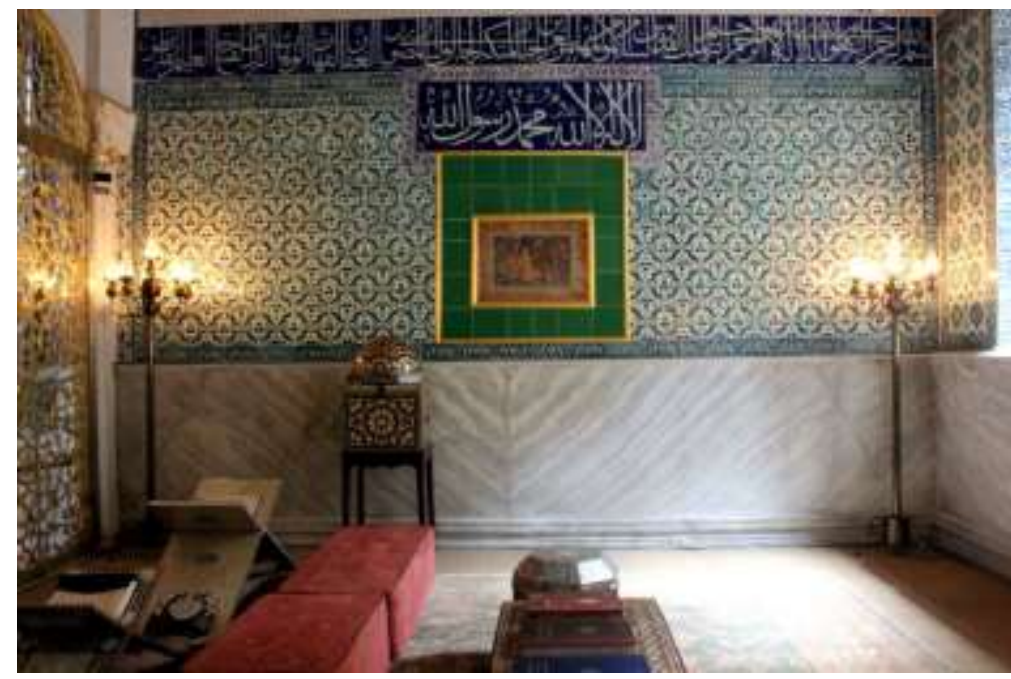

4: Okuma Odası D duvarında çini kitâbeler.

Mimarî eserlerin duvar, kemer, fil ayakları ve tavan gibi geniş yüzeylerinin bezemesinde kullanılan ulama çiniler, kompozisyonun dört tarafından veya iki yönden katlanarak veya taşınarak çoğaltılması suretiyle oluşturulur. (Turan Bakır,1999: 216.) Okuma Odası'nın duvarları ve pencere içleri ulama çinilerle kaplanmıştır. Bunlardan ilki D Duvarında yer alır. 18. yüzyıl Tekfur Sarayı imalatı olan çinilerde, ortada üç benek motifi ile bunları çevreleyen kaplan postu motifi kullanılmıştır. Bu ikisi arasındaki boşluklar serbest dolantı bulut motifleriyle doldurulmuştur. (Fotoğraf 5) Desen dört tarafindan katlanarak çoğaltılır. Aynı duvarda yer alan bir diğer Tekfur Sarayı çinisi ise duvarın ortasındaki I. Mahmud tuğrasının zemininde paspartu vazifesi gören, etrafı altın çerçeve ile çevrilmiş düz yeşil renkli çini kaplamalardır.

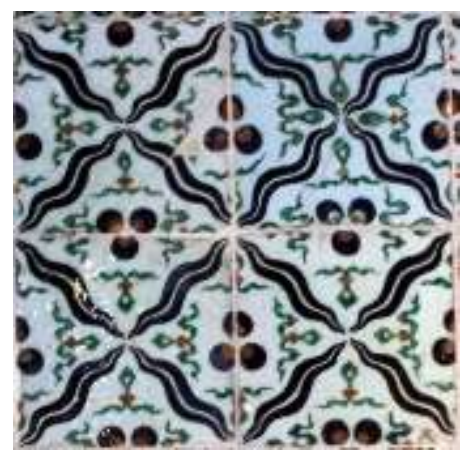

5: Okuma Odası D Duvarı Tekfur Sarayı çinileri.

Pencerelerin bulunduğu duvarda birbirinden farklı desenlerde ulama çiniler kullanılmıştır. E1, E2, E5, E9, E10 Duvarlarında yer alan çinilerde desen, kompozisyon sahasının merkezine yerleştirilen hatayi motifinden çıkan ve helezon meydana getiren saplarla oluşturulmuştur. (Fotoğraf 6) Çinilerin soluk mavi zeminleri 18. yüzyıl Tekfur Sarayı üretimi olduklarına dair ipucu verir. Pencere içlerinde, E 4, E 6 ve E 8 duvarlarına yerleştirilmiş olan ulama çinilerde merkezdeki penç motifinden çıkan yaprak ve goncaların bulunduğu dallar çarkıfelek formunda ortadaki pencin etrafında dönerler. Dendanlı kapalı bir form içine alınan desende dört kenarda kalan boşluklar rumilerle doldurulmuştur. (Fotoğraf 7) E 12 duvarında ise yukarıya doğru ilerleyen ince saplar 
üzerinde küçük hatayi gonca ve yaprakların oluşturduğu bir desen görülür. (Fotoğraf 8) Pencere ile kapı arasındaki duvar yüzeylerinde üç farklı desende çini kaplama bulunur. F Duvarında yarı stilize çiçeklerle meydana getirilmiş ulama çiniler yer alır. (Fotoğraf 9) E 13 Duvarını, içi rumi bezeli iri madalyonlarla oluşturulmuş olan çiniler bezer. (Fotoğraf 10) Kapı kenarındaki G Duvarı ise üst sıradaki 5 adet beyaz çini karo hariç bütünüyle eski onarımlarda takılan imitasyon çinilerle kaplanmıştır. (Fotoğraf 11) (İstanbul Restorasyon ve Konservasyon Merkez ve Bölge Laboratuarı Müdürlüğü, Ayasofya Müzesi I. Mahmud Kütüphanesi Eski Onarımlar Sirasında Yerinden Alınarak Orijinal Çinilerin Yerine Takılan Imitasyon Çini ve Fayansların Tespit Projesi, 2012-2013: 7)
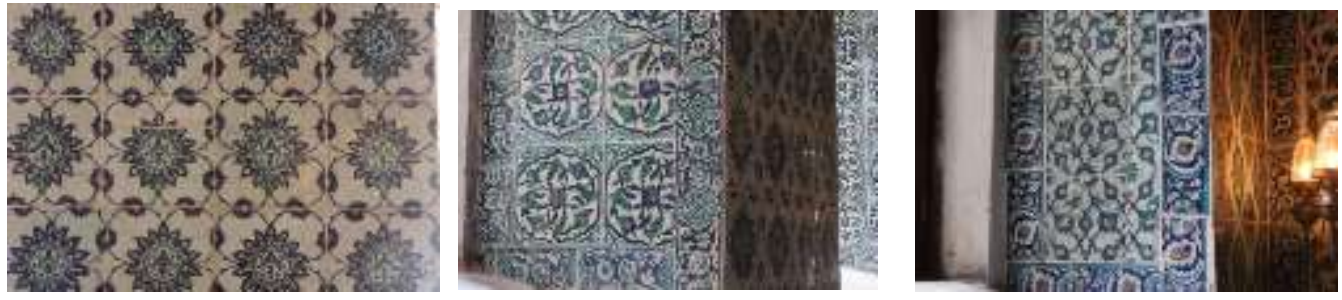

6-8: Okuma Odası Pencereli duvarlarda yer alan ulama çiniler.
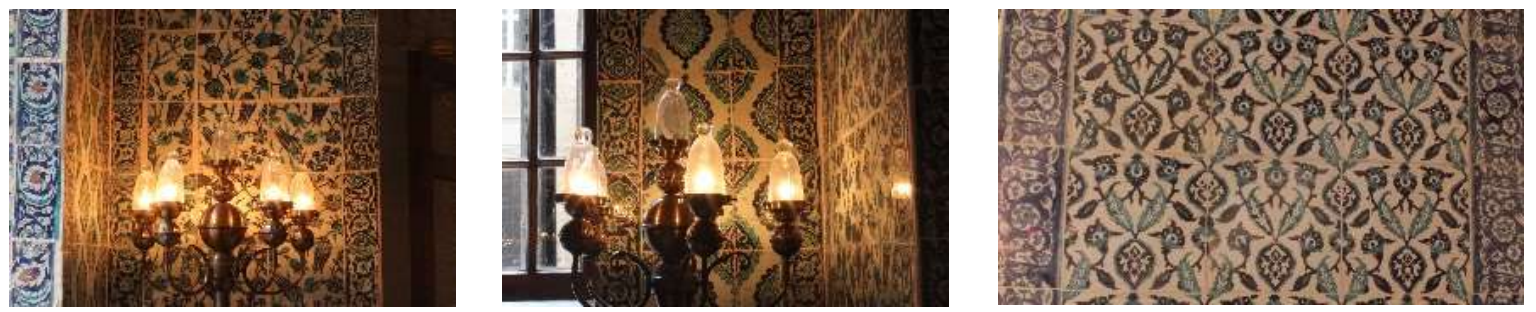

9-11: Pencere ile kapı arasındaki duvar yüzeylerinde kullanılan çiniler.

Ulama kompozisyonlu çinilerin etrafını yer yer iki sıra ve genellikle tek sıra olarak bordürler çevirir. Çini kitabeler ile ulama çinilerin çevresine kullanılan bordürlerde birbirinden farklı kompozisyonlar yer alır. Kelime-i tevhid levhasının etrafındaki mavi beyaz 18. yüzyıl Kütahya imalatı bordürde desen kıvrık dallar ve bunların arasındaki hatayi motifinin tekrarından meydana gelir. (Fotoğraf 12) Duvarın tamamındaki çinilerin çevresinde kullanılan bordürde ise sırasıyla bir hatayi ve bir pençten çıkan ve yan yana yapraklarla tamamlanan bir desen görülür. (Fotoğraf 13) Pencerelerin bulunduğu cephede yer alan bordürlerde üç farklı desen ile karşılaşılır. Bunlardan ilkinde kompozisyon küçük şemse motifleri ile bunlardan çıkan yarı stilize çiçekli ve hatayili saplarla oluşturulmuştur. Lacivert zemin üzerinde yer alan motiflerin beyaz birakılan kısımları haricindeki yerler turkuvaz ile boyanmıştır. (Fotoğraf 14) Diğer bordürde ise iri çizilmiş bir hatayi ve penç motifinin ve bunlardan çıkan yapraklı dalların oluşturduğu bir desen yer alır. G Duvarında yer alan imitasyon çinilerin etrafındaki bordürde penç, rumi ve goncalarla oluşturulmuş bir kompozisyon görülür.
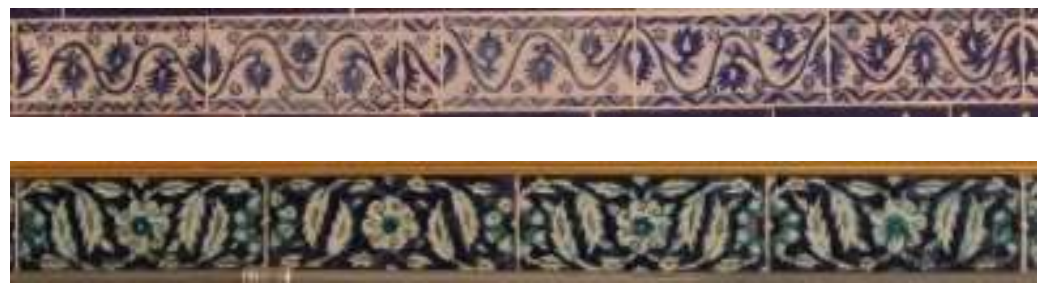


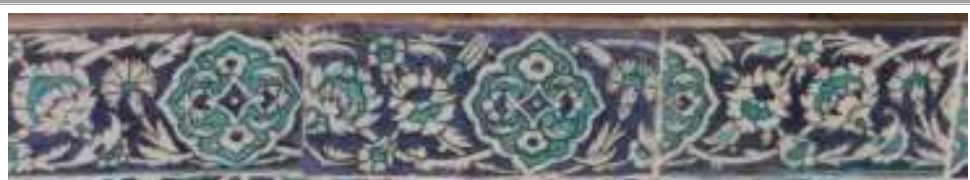

12-14: Okuma Odası E Duvarı bordürleri.

\subsection{Koridor}

Okuma salonu ile Hazine-i kütübü L biçiminde ve tonozla örtülü bir koridor birbirine bağlamaktadır. Koridorun geniş mermer pervazları ve ahşap kanatları olan kapısının iki yanı 16. yüzyıl çinileri ile bezenmiştir. Kap1 üzerinde celî sülüs ile Kelime-i Şehâdet yazar. Koridor duvarları yerden itibaren yarıya kadar karışık bir şekilde 16 . ve 17. yüzyıl, 18. yüzyıl ulama ve bordür çinileriyle, 19. yüzyıl Fransız fayanslarıyla, pano ve çini kitâbelerle kaplıdır. Koridor çinileri arasında şüphesiz en dikkati çekeni 16. yüzyıla tarihlenen, karşı karşıya iki duvara yerleştirilmiş olan iki adet panodur.

Koridorun sağ duvarında, J1 Duvarı, ulama çinilerin arasında yer alan simetrik panoda kompozisyon bahar ağacı ve köşebentlerden oluşmaktadır. Zeminde bulunan tek sıra yığma bulut motifi ve bunun üzerine yerleştirilmiş olan yaprak kümelerinin arasından çıkan bahar ağacı, dallarına sıra sıra dizili çiçekleriyle yukarı doğru ilerleyerek bütün sahayı bezer. Aşağıdaki yaprak kümelerinin arasına iri laleler ve minik kokulu menekşeler ile aynı safâ çiçekleri yerleştirilmiştir. Panonun alt kısmında köşeden çıkan bir diğer yaprak kümesinin içinde ise karanfil demetleri, iri güller, küçük menekşeler ve peygamber çiçekleri yer alır. Kenarlarda tepelik rumiler, yukarı kısımlarda ağaç dalları arasında yığma bulutlar küçük boşlukları tamamlamak için kullanılmıştır. Yukarıdaki köşebetlerde hurdeli rumilerle meydana gelen bir kompozisyon görülür. Ende 6, boyda ise 7 karodan meydana gelen panonun bir bordürü bulunmaz. Beyaz zemin üzerine kobalt mavi, mercan kırmızı, kahverengi, zümrüt yeşili ve lacivert renklerin kullanıldığı 16. yüzyıl İznik üretimi olan panoda herhangi bir deformasyon görülmemektedir. (Fotoğraf 15-16; Çizim I-Ia)
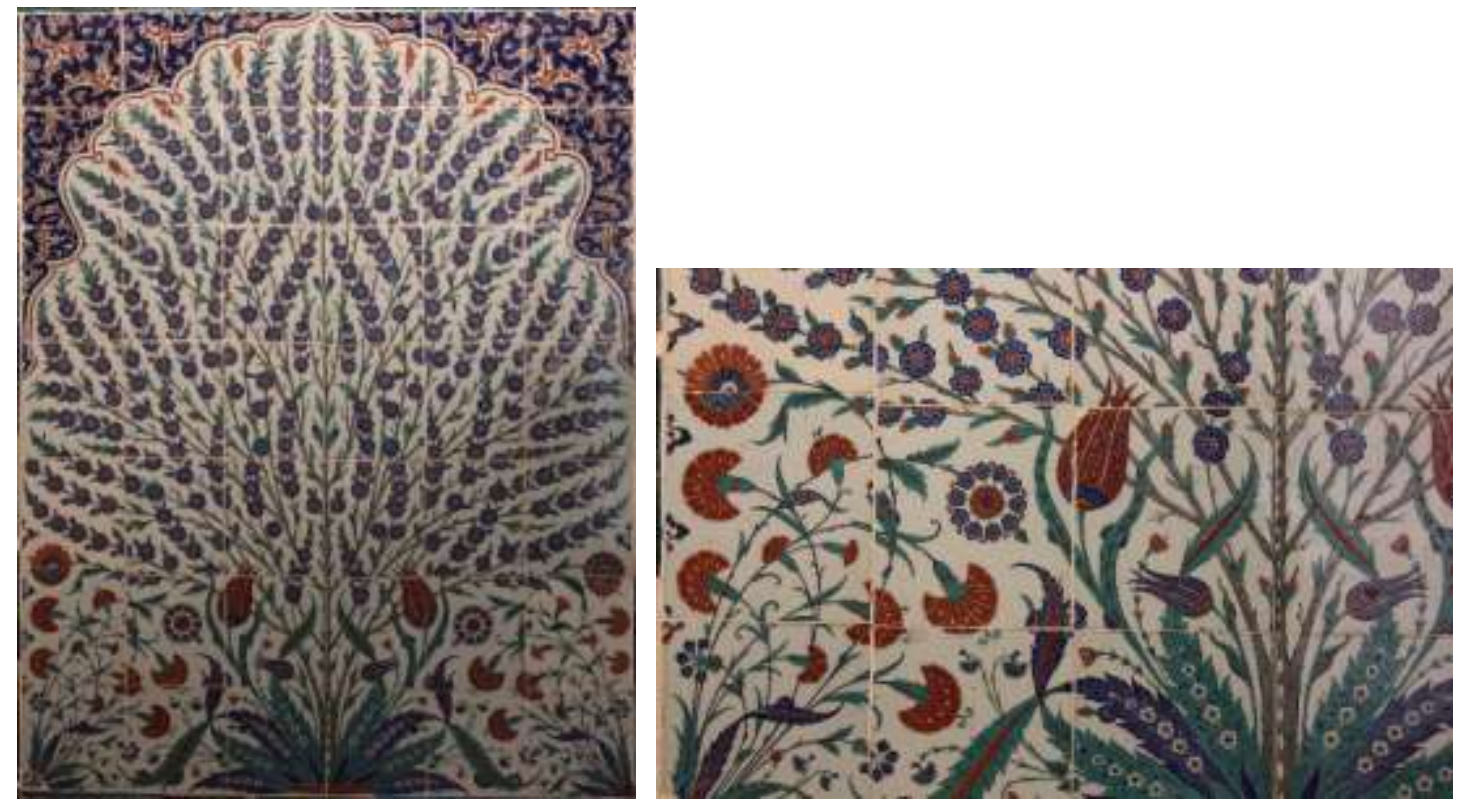

15-16: Koridor, J1 Duvarı çini panosu ve detayı. 


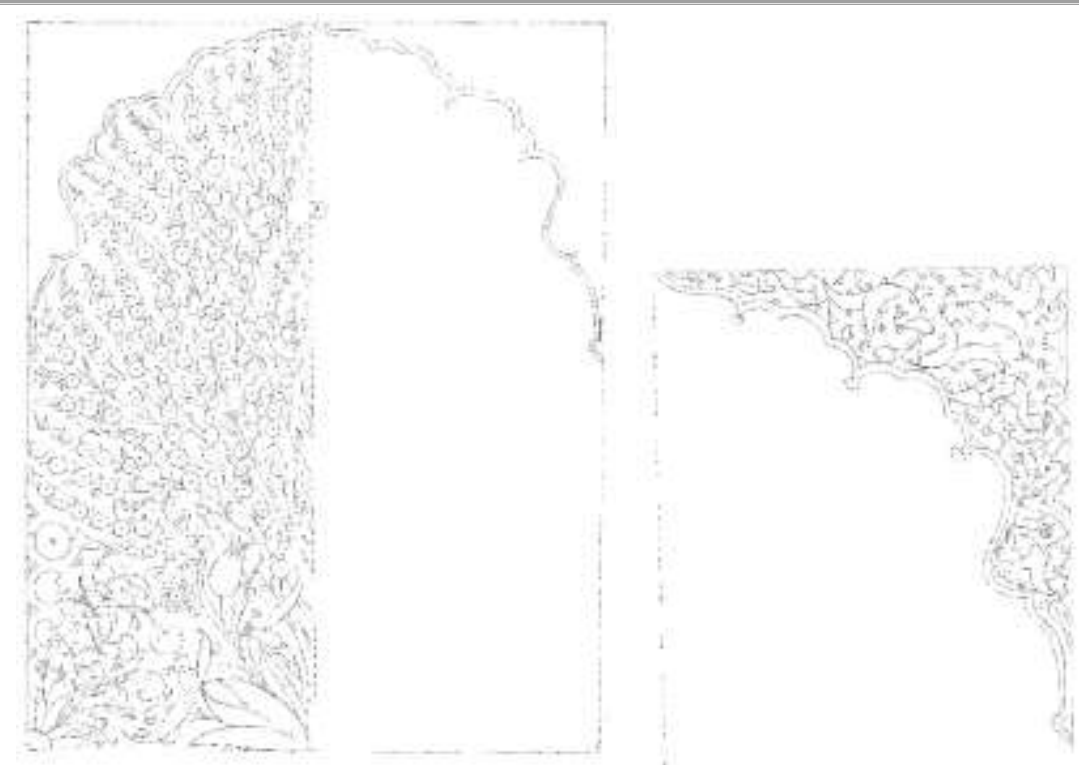

I-Ia: Koridor, J1 Duvarı çini pano şeması ve köşebenti.

Koridorun sol duvarında, A5 Duvarı, bahar ağaçlı panonun karşısında bir pano daha bulunur. Ana temada hatayi ve yapraklarla oluşturulan simetrik bir kompozisyonun yer aldığı pano dört kenarından tepelik bordürü ile çevrilmiştir. Zeminden çıkan biri iri ve açık saz yapraklarını diğeri ise hatayileri taşıyan iki dalın helezoni hareketlerle birbiri arasından geçerek yukarıya doğru ilerlemesi ile meydana gelen kompozisyon, yukarıda rumili köşebentlerle tamamlanır. Desen aşağıya ve yanlara doğru genişletilebilecek șekilde tasarlanmış, bordür ile birlikte karolara aktarılmıştır. Ende 3, boyda 6 parçadan oluşan panoda beyaz zemin üzerinde kobalt mavi, soluk bir kırmızı, yeşil ve lacivert renkler kullanılmıştır. 16. yüzyıl İznik ürünü olan panoda herhangi bir deformasyon görülmez. (Fotoğraf 17-18; Çizim II-IIa)
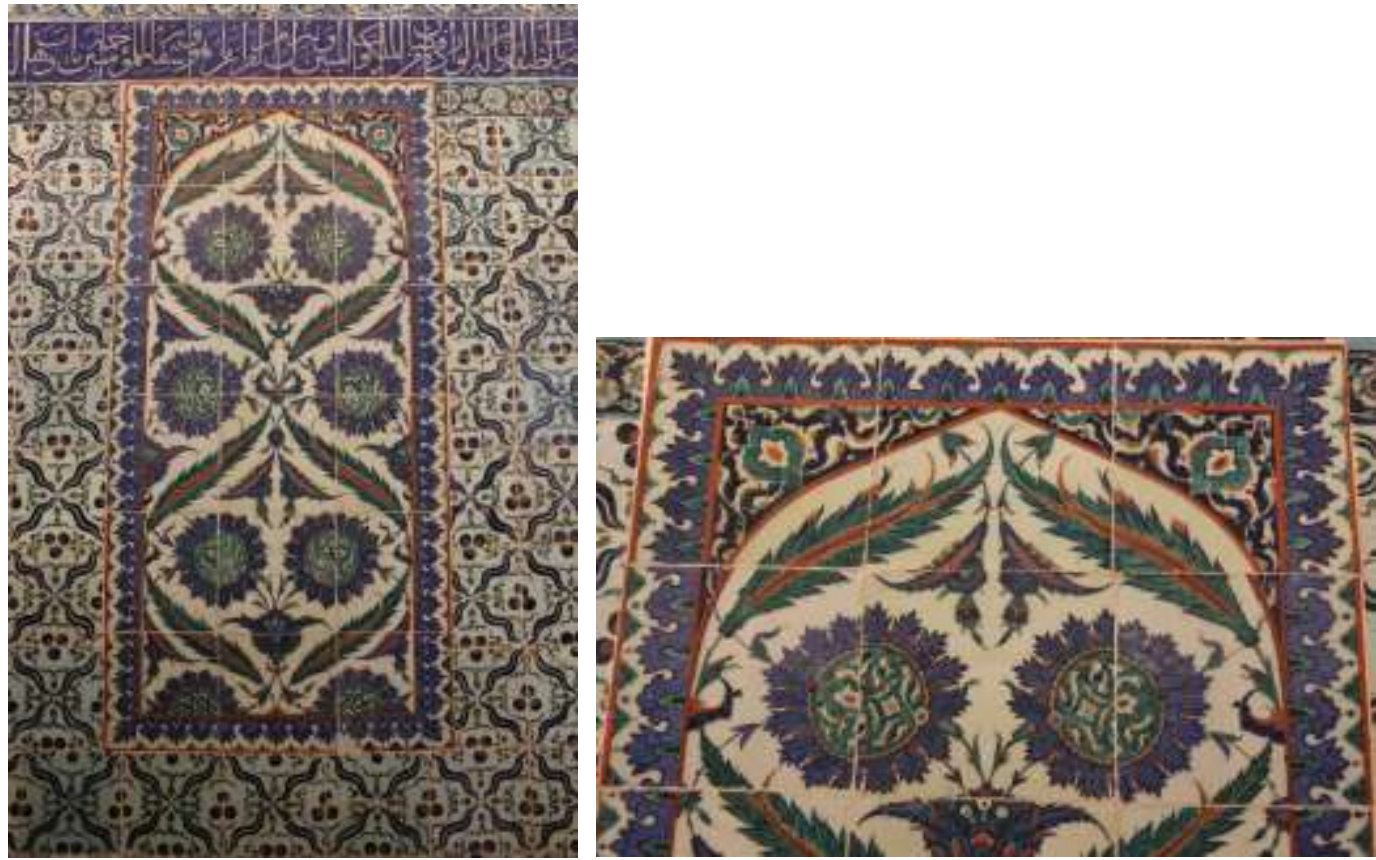

17-18: Koridor A5 Duvarı çini panosu ve detay1. 


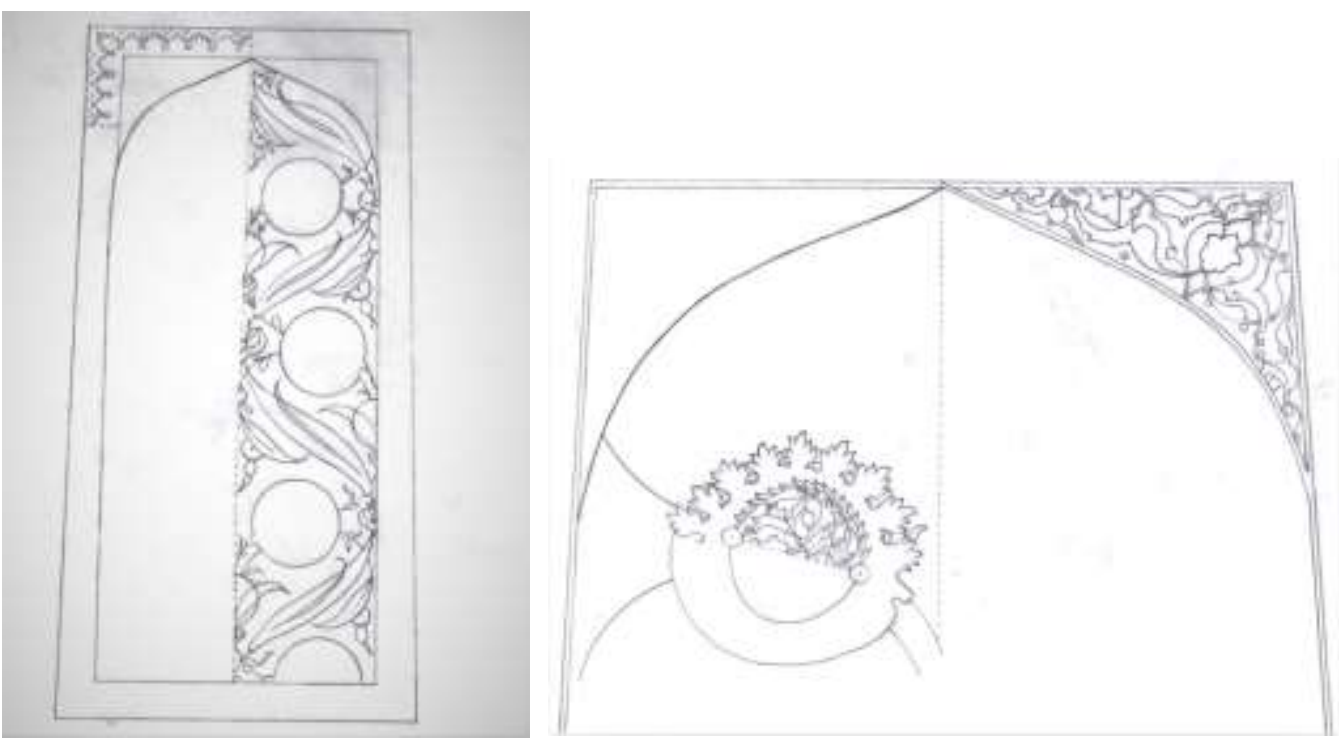

II-IIa: Koridor, A5 duvarı çini pano şeması ve detayı.

Koridor bölümünde, 16 yüzyıl İznik çinileri, Tekfur Sarayı çinileri, 17. yüzyılın mavi beyaz ulama çinileri ile sarı renkli İtalyan çinileri ve Fransız imitasyon çiniler duvarlarda karışık bir şekilde kullanılmıştır.

Koridorun sağ tarafindan başlayarak çini bezemelerin üzerinden geçen ve tüm mekanı dolaşan çini yazı kuşağı, lacivert zemin üzerinde beyazla ve celî sülüs ile Arapça dualar içerir. Çini kitâbelerin okunuşu ve anlamı şöyledir:

“'Allahümme 'c'ali'l-Kur'âne rabî'a kulûbinâ ve șifâe sudûrinâ ve celâe ehzâninâ ve zehâbe humûminâ ve se'ate fì erzâkınâ ve sâikanâ ilâ cennâtike'n-ne'îmi bi rahmetike yâ erhame'r-Râhimîn ve bihî neste'înu. Allahümme'c'al ed-du'âe lenâ necâten min külli kerbin ve âmennâ min külli havfin ve 'ssmetin min külli sû'in ve şifâ'en min külli dâ'in bi rahmetike yâ Kerîm. Şedîdü's-sultâni külle yevmin hüve fì şe'n. Allahümme sekkir sadmeten bismillahi mâ şâallahu kâne bismillahi aleyye'ş-şe'nü 'azîmü'l-burhâni hattâ neteşebbesü bi ezyâli lutfike ve bike ne'tesımu min nüzûli kahrike yâ Kerîmu bi hurmeti seyyidi'l-mürselîne ve senedi'l-mukarrabîne haysü enzelte fì kitâbik. Heyyebet kahramâne ve licübbirat bi'l-latîfeti'n-nâzileti'l-vârideti min feyezâni'l-melekûti'l-mübîn. Ve nünezzilü mine'l-Kur'âni mâ hüve şifâün ve rahmetün li'l-mü'minîne yâ Vehhâbe'ş-şâmileti yâ erhame'r-râhimîn yâ zü'l-kuvveti'l-kâmileti'l-kudreti. "

“Allahım, Kur’ân'1 kalplerimizin baharı, gönüllerimizin şifâsı, hüzünlerimizin cilâsı, gamlarımızın gidericisi, rızkımızda genişlik ve Naîm Cenneti'ne rehberimiz yap, ey merhametlilerin en merhametlisi! Senden onunla yardım isteriz. Allahım! Duayı bize tüm üzüntülerden kurtuluş eyle. Bizi bütün korkulardan emin kıl, kötülüklerden koru, rahmetinle hastalıklara şifầ eyle ey Kerîm! 'O her zaman yaratma hâlindendir. 55/29.' Allahım, darbelerden/çarpmalardan isminle dilediğin gibi muhafaza eyle. Kendisine dayandığımız, varlı̆̆ının delilleri büyük, şânı yüce Allah'ın adıyla. Musibetlerin sıkıntıların inmesinden kitabında gönderdiğin nebîlerin ve yakınlarının dayanağı ile Sana ve lütfuna sığınırız yâ Kerîm! İndirdiğin kitabının, lütfuyla teselli eden, kahrıyla korkutan, mânâ âleminin feyiz pınarlarından apaçık nâzil olan şu âyetinde vârid olduğu gibi: ' Ve Biz mü'minlere şifâ ve rahmet olan Kur'ân'1 indiririz. 17/82.' Ey bağışlaması kuşatıcı olan, merhametlilerin en merhametlisi, kâmil kuvvet ve kudret sâhibi." 


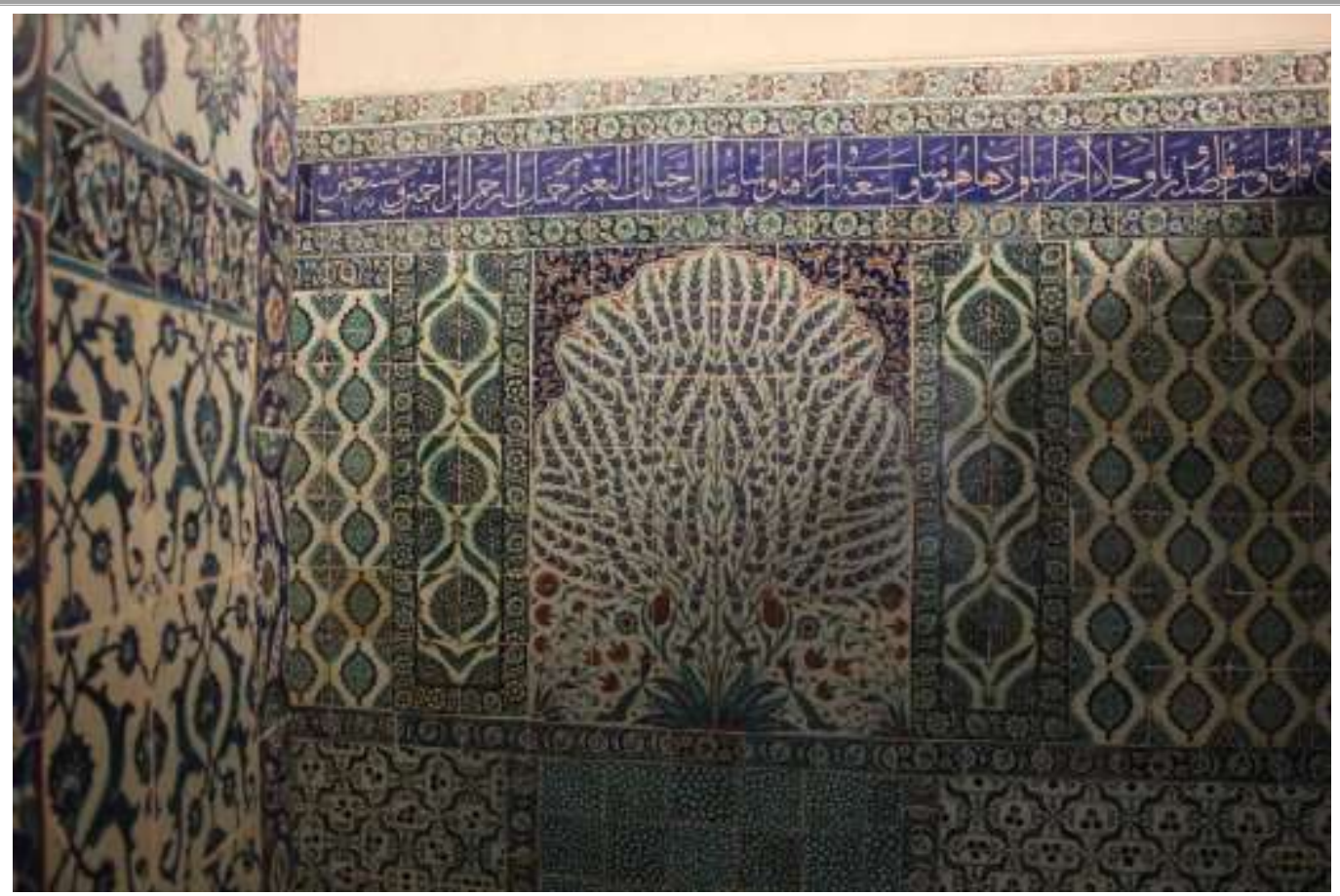

19: Koridor J1 Duarında çini yazı kuşağı ve çeşitli devirlere ait çini kaplamalar.

Koridorun bitiminde Hazine-i kütübün kapısı yer almaktadır. Kapının girişinde karşılıklı olarak sağda ve solda birbirine eş servi ağaçlı iki pano daha bulunur. Asıllarının yerlerine 18821896 onarımlarında yerleştirilmiş olduğu söylenen servili panoların arka yüzeylerinde Fransa'da üretim yapan Choisleroi Seine atölyesinin ismi basılıdır. (Çini Koruma Onarımı Uygulama Raporu, 2012: 1-3.) (Fotoğraf 20)

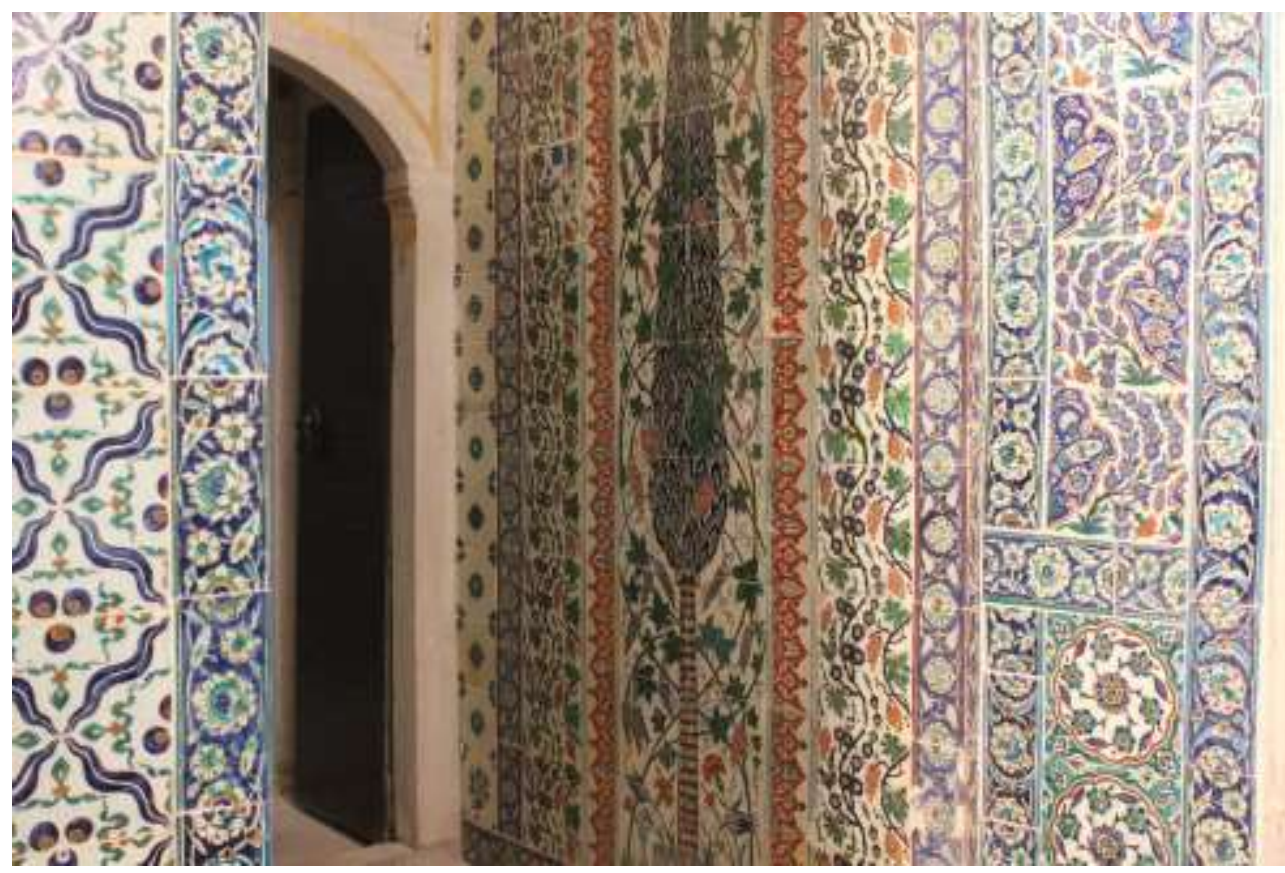

20: Koridor G1 Duvarında 16. Yüzyıl İznik, 18. Yüzyıl Tekfur Sarayı ve Fransız imitasyon çiniler.

\subsection{Hazîne-i Kütüb}

www.turkishstudies.net/turkishstudies 
Hazine-i kütübe, üzerinde celî sülüs ile besmele-i şerîf yazan mermer söveli ve demir kanatlı bir kapıdan geçilerek girilmektedir. Kapının diğer yüzünde kemer alınlığında Sultan Mahmud'un tuğrası yer alır. Kapı kemerinin üzerine yerleştirilen dikdörtgen saha içerisindeki on beş satırlık manzum inşâ kitabesinin / tarih manzûmesinin metni ta'lik yazıyla ve Arapça olarak Kütüphane'nin bânisi Sultan I. Mahmud'a medih ve duaları içerir. H. 1153 senesine tarih düşürülerek tamamlanan kitabede, son satırda hattatının ismi yer alır. $\mathrm{Bu}$ tarih manzumesi, Kütüphane için dönemin tanınan ve az bilinen şairleri tarafından yazılan dokuz manzumeden en beğenileni olmalıdır. Manzumenin şairi ise henüz bilinmemektedir. (Aynur, 2014: 692). ${ }^{3}$

Hazine-i kütüb, iki kısımdan meydana gelmektedir. Kapıdan girildiğinde sekizgen ve yüksek kasnaklı bir kubbenin örttügü kare planlı mekanı, kubbenin tam altına yerleştirilmiş olan ahşap kitap dolabı neredeyse bütünüyle doldurur. Kubbe üzerinde altı pencere bulunmaktadır. Beyaz sıva üzerinde malakâri bezemeleri olan kubbenin sekizgen kasnağında siyah zemin üzerine altınla ve celî sülüs ile Fâtır Suresi 29-32. ayetleri yazılıdır. Kubbedeki kuşak yazısının hattatı aynı zamanda Ayasofya Şadırvanı'nın da hattatı olan Baltacızâde Mustafa Paşa'dır. (Müstakımzâde, 1928: 541; Suyolcuzâde, 1942: 121.)

Hazine-i kütübün ikinci kısmı birincisinden bir seki ve mermer sütunlar ile ayrılmaktadır. Burası dikdörtgen planlıdır ve aynalı tonoz ile örtülüdür. Hazine-i kütüb, alt ve üst kat pencereleri sayesinde kısmen aydınlıktır. Alt kat pencerelerin üzerinden geçerek tüm odayı dolaşan yazı kuşağında, bordo renk zemin üzerine altınla ve ta' lik yazıyla Arapça el-Kasîdetü'l-münferice' den beyitler yer alır. ${ }^{4}$ Hazine-i kütüb, kubbenin altına yerleştirilen büyük ahşap kitap dolabı, kitap dolabının nesih ve ta'lik kitabeleri, madenî askı toplar, büyük boy ahşap kasalı duvar saati ile oldukça özenilerek tefriş edilmiş bir mekandır. Bunların yanı sıra dikkati çeken en önemli özelliği yerden tavana kadar tüm duvarları ile pencere içlerini ve dolap nişlerini bezeyen çinileridir. Azade Akar'ın, padişahın izni ile sarayın çini hazinesinden naklolunduğunu söylediği (Akar, 1971: 286.) İznik çinileri pano, ulama çiniler, bordürler, pencere köşelikleri ile süpürgelik çinileridir. Kütüphanede ayrıca eski onarımlar sırasında orijinallerinin yerine ikāme edilmiş olan 19. yüzyıl Fransiz fayansları bulunur.

\footnotetext{
${ }^{3}$ Kütüphanenin kitabeleri için bkz: Akgündüz vd, 2005: 434-441; Berk, 2006: 66-67; Aynur, 2014: 688-692.

4 İbnü’n-Nahvî'nin (1041-1119) el-Kasidetü'l-münferice isimli kasidesi yıllar içerisinde büyük üne sahip olmuş, sıkıntılı ve kederli zamanlarda okunması alışkanlık edinilen bir dua halini almıştır. Kaside'nin pek çok tercüme ve şerhi bulunur. Elmalı ve Durmuş, 2000: 163-164.
} 


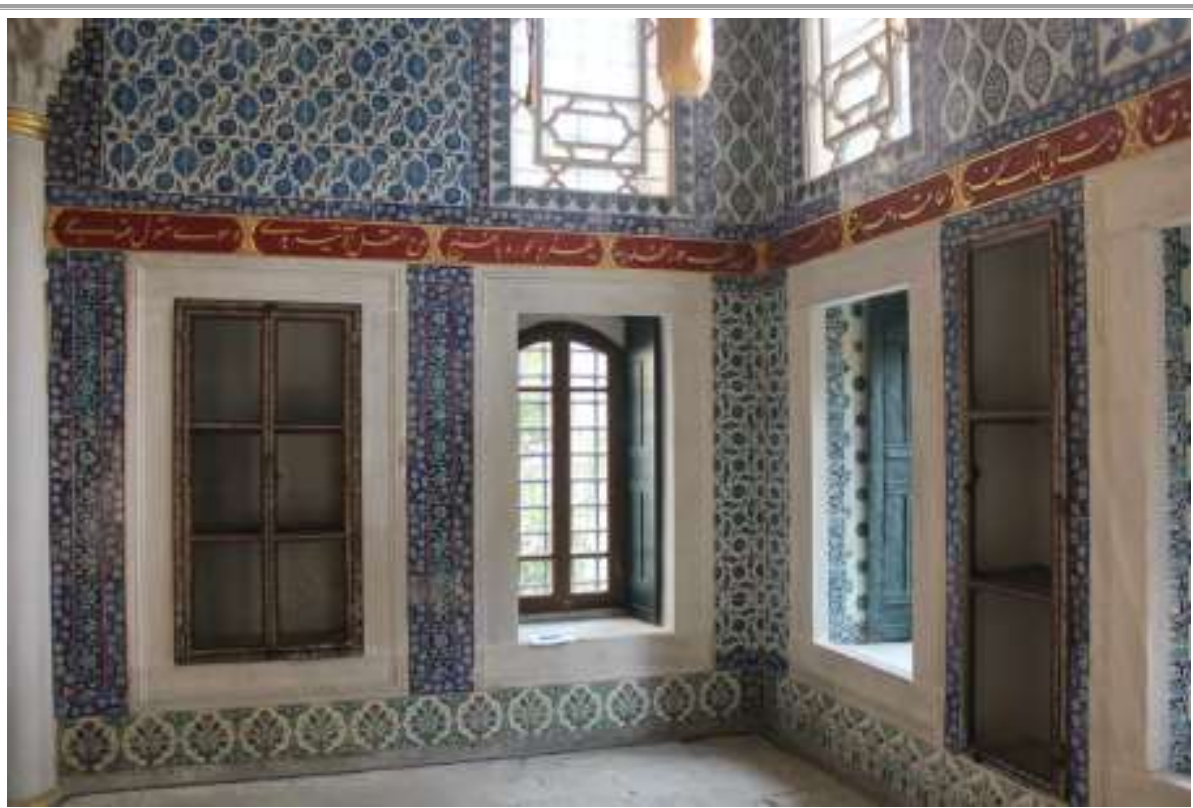

21: Hazine- kütüb E ve D Duvarında 16. yüzyıl çinileri ile imitasyon süpürgelik çinileri.

Hazine-i kütübde bulunan yegâne çini pano, dikdörtgen planlı kısımda giriş cephesinde, F Duvarı, üstte, köşede yer almaktadır. Sivri kemer ve tepelik bordür ile tamamlanan dikdörtgen bir saha içerisindeki panoda, ana temada aşağıda bir vazo ve simetrik hatayî motifleriyle oluşturulmuş bir desen yer alır. Köşebentler ise yarı stilize çiçeklerle bezenmiştir. Aşağıda, vazonun yanındaki yaprak kümesinin arasından çıkan dallar geniş helezoni dönüşlerle, simetri eksenindeki iri motiflerin ve birbirlerinin içinden geçerek yukarıya doğru ilerlemektedir. Vazodan çıkan ince, uzun ve katlanmış bir saz yaprağı içeriye doğru genişçe kıvrılarak orta kısımda kapalı bir form oluşturur. Dallar üzerinde çok çeşitli, iri ve görkemli hatayîler, pençler, goncalar ve iri, ahenkli saz yaprakları bulunur. Aşağıdaki ayaklı, kulplu ve oval gövdeli vazonun içi simetrik, rumili bir desen ile bezenmiştir. Beyaz zemin üzerinde kobalt mavi, mercan kırmızı ve zümrüt yeşili renklerin kullanıldığı 16. yüzyıl İznik üretimi olan panoda kırık ve çatlaklar görülür. İki farklı yerde desen akışı bozulmaktadır. Panonun iki uzun kenarında yarım motifler bulunur. (Fotoğraf 22-23; Çizim III-IIIa,b) 

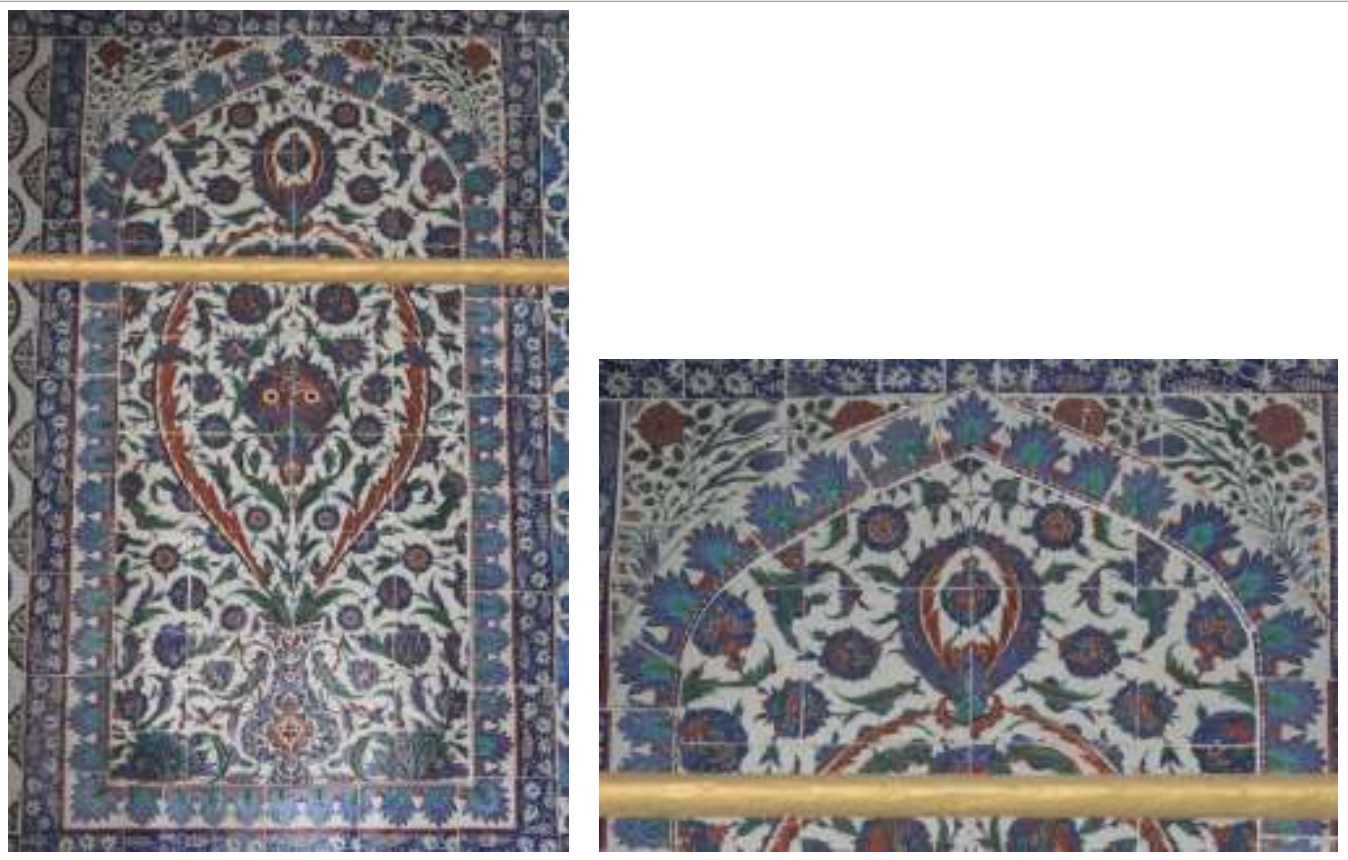

22-23: Hazine-i kütüb çini panosu ve detayı.
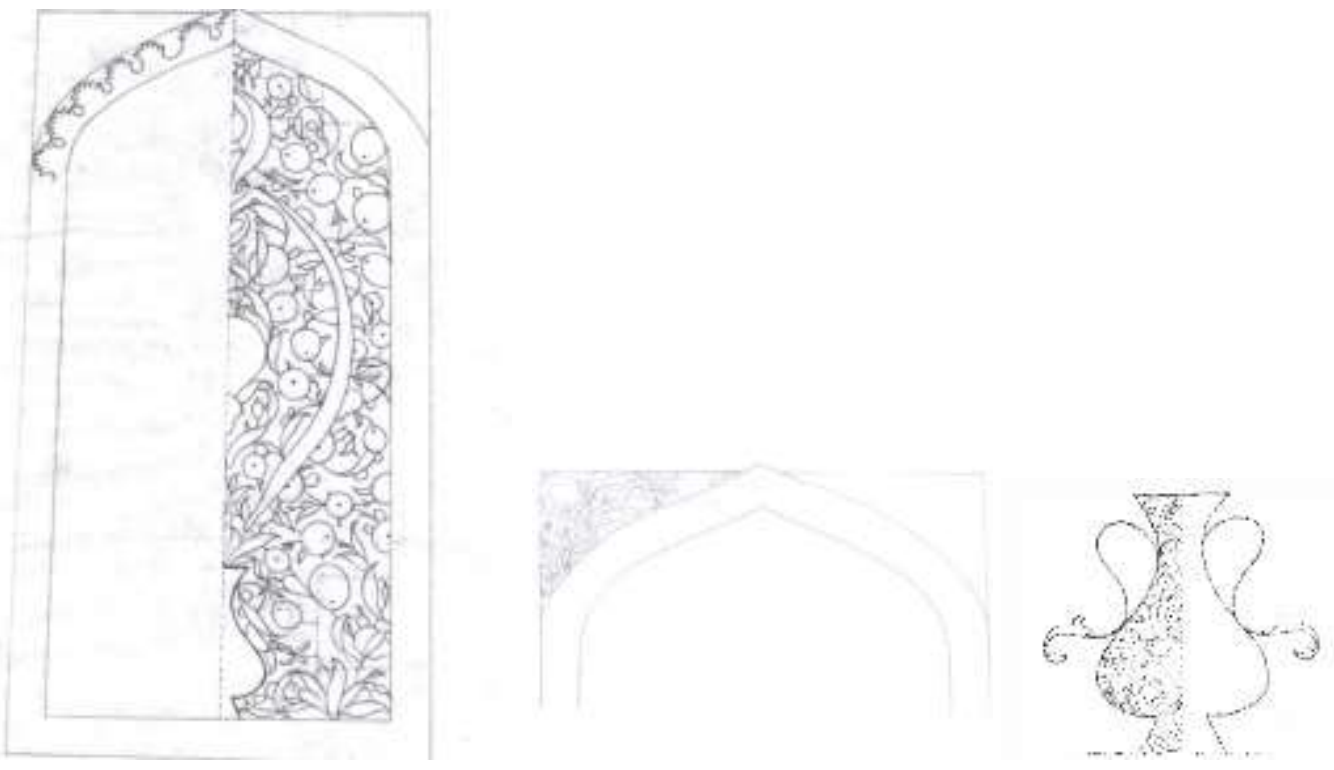

III-IIIa,b: Hazine-i kütüb çini panosu ve detayları.

Hazine-i kütübde, alt ve üst kat duvarlar bütünüyle birbirinden farklı desendeki ulama çinilerle bezelidir. Bu çiniler 16., 17. ve 18. yüzyıl çinileri olarak sırasıyla anlatılacaktır:

16. yüzyıla tarihlenen ulama çinilerden ilki F ve D Duvarlarında kullanılan mavi beyaz çinilerdir. Tek karoda tasarlanan desende, penç motifinden çıkarak iki yöne devam eden dallar ve bu dallar üzerinde hatayi ve yapraklar yer alır. Simetri eksenine yerleştirilmiş olan iki hatayi motifi ile sağa ve sola katlanarak geçirilen desen yukarıya doğru taşınarak biteviye çoğaltılabilir. (Fotoğraf 24) F Duvarında kullanılan ve aynı yüzyıla tarihlenen diğer bir desende, tek karoda köşelere çeyrek ve kenarlara yarım penç motifleri yerleştirilmiştir. Köşelerden iki kıvrımlı sap, lale motifleri ile merkeze doğru uzanarak sonlanırken, bunlardan iki yönden çıkan ve iki yöne doğru uzanan hatayili dallar merkezde sıra sıra ve ahenkli bir düzen oluşturur. Desen dört karoda 
tasarlanarak her yöne çoğaltılmıştır. Beyaz zemin üzerinde kobalt mavi, mercan kırmızısı ile turkuvaz kullanılmıştır. (Fotoğraf 25) Hazine-i kütübün tüm duvarlarının üst kısımlarında görülen ve aynı yüzyıla tarihlenen bir diğer ulama desende, tek karoda ortada tam ve köşelerde çeyrek olarak şemseler bulunur. Şemse formunun içi yarı stilize çiçeklerle bezelidir. Beyaz zemin üzerinde kobalt mavi, mercan kırmızı ve zümrüt yeşilinin kullanıldığı desen her yöne çoğaltılabilir. (Fotoğraf 26) Aynı desenin yeşil rengin belirginleştiği imitasyonu ise D Duvarında kullanılmıştır. D duvarında, duvarın C ile kesişim yerinde kullanılmış olan bir diğer 16. yüzyıl çinisinde ise tek karoda etrafı dilimli madalyon formu içerisinde penç motifleri ile oluşturulmuş ahenkle dönen bir kompozisyon görülür. Madalyon formunun dışındaki dörtgen sahanın köşeleri ise ortabağ ve gonca motifleri ile simetrik olarak tamamlanmıştır. (Fotoğraf 27) Tüm duvarlarda görülen bir diğer ulama desen yine tek karoda tasarlanmıştır. Kompozisyon, merkeze tam ve dört kenara yarım olarak yerleştirilen penç motifleri ile merkezdeki motiften çıkıp yarım motiflerin arasından geçerek ortada buluşan hareketli ve ahenkli dallardan oluşur. Beyaz zemin üzerinde kobalt mavi, mercan kırmızı ve az miktarda turkuvaz renklerin kullanıldığı desen her yöne doğru çoğaltılabilir. (Fotoğraf 28)
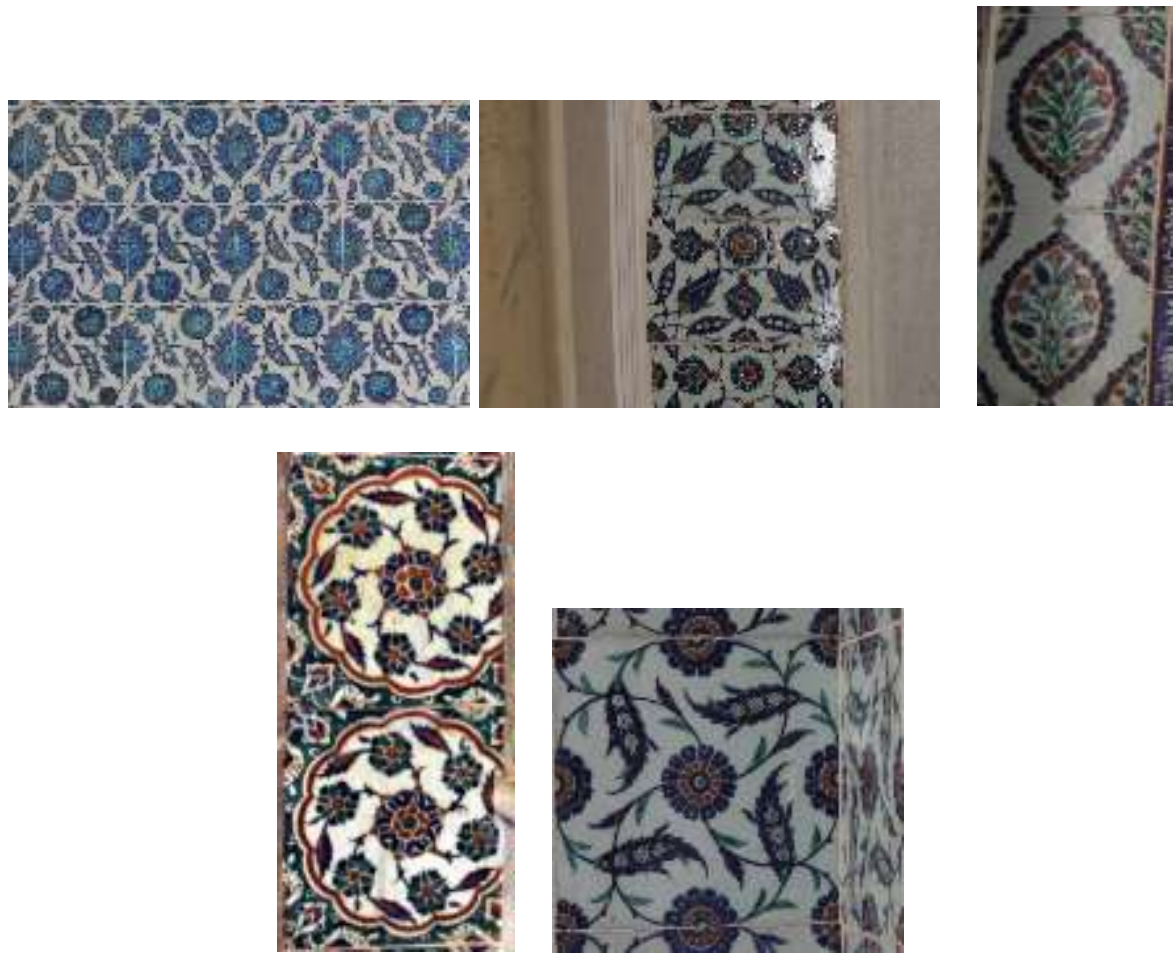

24-28: Hazine-i kütüb 16. yüzyıl ulama çinileri.

Kütüphane'nin Okuma Odası ve Koridorunda kullanılmış olan ve 18. yüzyı1 Tekfur Sarayı'na mâledilen üç benek motifli ulama çiniler Hazine-i kütübde F ve D Duvarlarında da yer almaktadır. E ve D Duvarlarında pencere içlerinde ve kitap nişlerinde üç farklı desendeki ulama çiniler de yine Tekfur Sarayı üretimi olmalıdır. Tek karoda ortada bir ve dört köşede dört çeyrek penç motifinin her yönde tekrarıyla meydana gelen ulama çinilerde, beyazımtrak zemin üzerinde petrol yeşili ile kobalt mavi kullanılmıştır. Kitap nişleri ise altta bir soğandan çıkan sümbül demetli çiniler ile bezelidir. Bu çinilerin bir diğer varyasyonunda yarı stilize bir çiçek motifi kullanılmıştır. (Fotoğraf 29-31) 

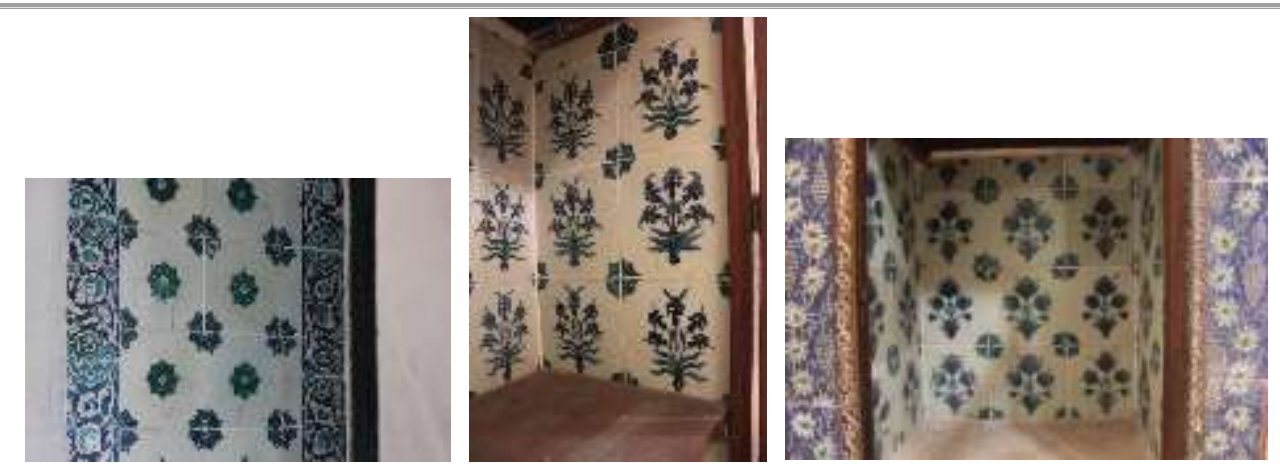

29-31: Hazine-i kütüb pencere içleri ve dolap nişlerinde kullanılan Tekfur Sarayı çinileri.

Bunlardan başka Kitap hazinesinde taklit ulama çiniler de bulunur. Bunlar C Duvarının üst kısmında, Pencere 2'nin her iki yanındaki laleli ulama çiniler ile D Duvarının üst kısımlarındaki pençli hatayili ulama çinilerdir. (Çini Koruma Onarımı Uygulama Raporu, 2012: 55)

Hazine-i kütübde her cephenin üst sınırını ve pencereler ile panonun etrafını çeviren tepelik bordürleri dilimli tepelik motiflerinin yan yana getirilmesiyle düzenlenmiştir. (Fotoğraf 32) Üst duvarlara yerleştirilmiş olan ulama çiniler ile alt duvarlardaki kitap nişlerinin çevresinde, aynı zamanda boş kalan dar sahaları doldurmada birbirinden farklı bordürler kullanılmıştır. Bunlardan ilki, Hazine-i kütübün dikdörtgen planlı ve bir seki ile yükseltilerek kubbeli ve kare planlı mekandan ayrılan yerin alt ve üst duvarlarında, ulama çiniler, pencere ve kitap nişlerinin çevresini dolaşarak odayı tesiri altına alır. Kobalt mavi zemin üzerinde asma yaprakları ve üzüm salkımları ile oluşturulmuş olan bordürde, desen iki yöne çoğalarak biteviye ilerler. Beyaz bırakılan yapraklar ile üzüm salkımlarının üzerine mercan kırmızı ve zümrüt yeşili ile süslemeler yapılmıştır. (Fotoğraf 26) Alt duvarlardaki ahşap kapaklı kitap nişlerinin arasında, üzüm salkımlı bordürler ile çevrili bir bordür daha bulunur. Buradaki dar sahayı bezeyen ve iki yöne katlanarak çoğaltılabilen bordür deseni, simetri eksenine sırasıyla bir ters ve bir düz olarak yerleştirilmiş olan hatayiler ile bu ikisini birbirine bağlayan, iri ve hurdeli bir rumiyi taşıyan hatın tekrarından oluşur. İki motif arasındaki boşluk ise hatayinin üstünden çıkan küçük dallarla doldurulmuştur. Kobalt mavi zemin üzerinde hatayiler beyaz bırakılmış, rumiler ise yeşile boyanmıştır. Motiflerin belirli yerlerinde mercan kırmızısı rengi kullanılmıştır. Aynı bordür D Duvarında tepelik bordürünün altında tek sıra olarak ve farklı desendeki ulama çinilerin arasında da yer almaktadır. (Fotoğraf 32) C Duvarında, üst kısımda, tek sap üzerinde iri bir lale ile hatayinin tekrarından meydana gelen bir bordür daha vardır. Kobalt mavi zemin üzerinde motiflerinin beyaz bırakıldığ 1 desen, motifleri üzerinde kullanılan mercan kırmızısı rengi ile dikkati çeker. (Fotoğraf 34) Hazine-i kütübde karşılıklı iki duvarda yer alan altı adet pencerenin duvar kalınlığından kaynaklanan iç kısmında, ulama çinilerin etrafı bir bordür ile çevrilidir. Kobalt mavi zemin üzerinde beyaz bırakılan ve üç ana dalda tekrar eden şemse, hatayi ve karanfil motiflerinin iki yandan simetrik olarak çoğaltılmasıyla oluşturulmuş olan çiniler 17. yüzyıla tarihlenmektedir. 


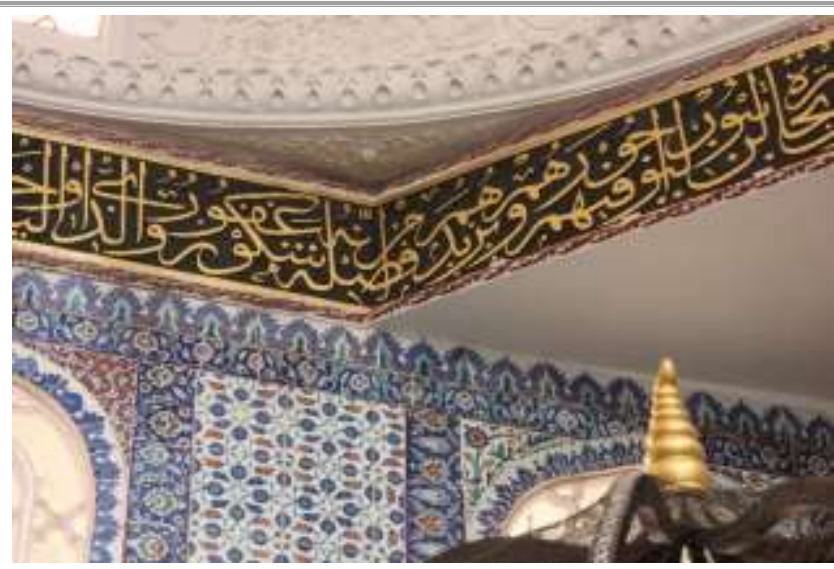

32: Bütün mekanda kullanılan 16. yüzyıl tepelik bordürünün C Duvarındaki görünümü.
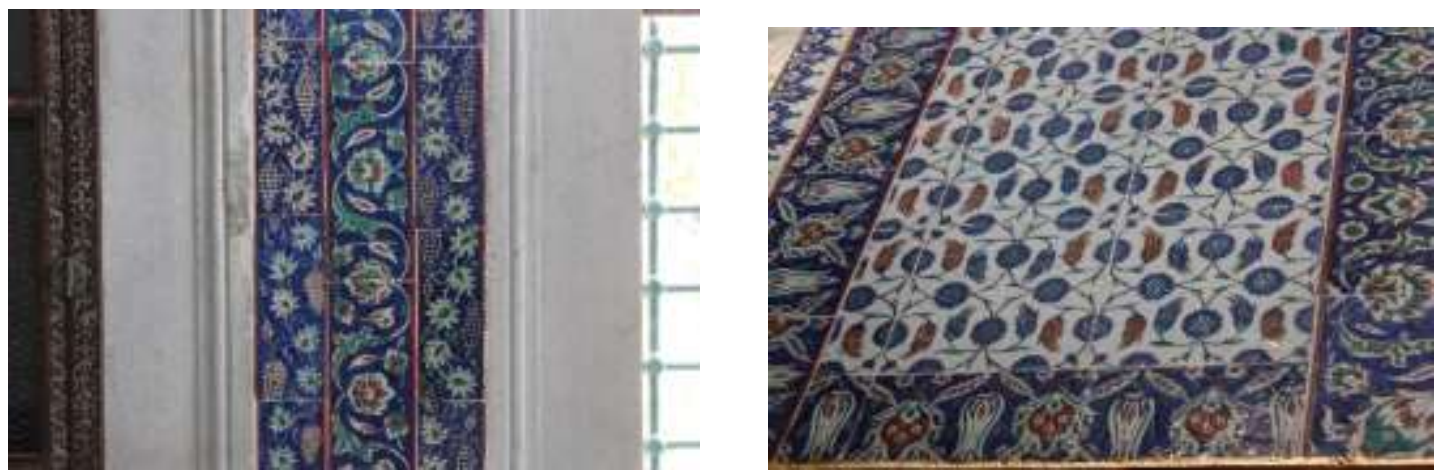

33-34: Hazine-i kütüb’ün 16. yüzyıla tarihlenen bordürleri.

Hazine-i kütübde D Duvarının alt kısmında bir birimde simetri eksenine yerleştirilen iki hatayi ve bunları birbirine bağlayan sap üzerinde bir hatayi motifi ve bunlardan çıkan yan dallarla meydana gelen bir bordür deseni daha vardır. Kütüphane'nin diğer bölümlerinde de kullanılmış olan çiniler 18. yüzyıla tarihlenir. (Fotoğraf 35)

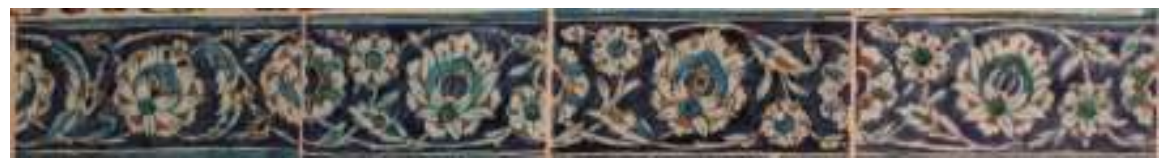

35: Tekfur Sarayı bordür çinisi.

F, C ve D Duvarının üst kısımlarında hatayi ve lale motifli imitasyon bir bordür kullanılmıştır. D Duvarında kullanılan imitasyon bir diğer bordürde ise kompozisyon, üstü bezemeli bir penç ile bunlar arasında üstü bezemeli iri bir yaprağın iki tarafa simetrik olarak devam ettirilmesiyle meydana gelir. Bir başka imitasyon bordür ise sirf rumilerle oluşturulmuştur. (Fotoğraf 36-38)

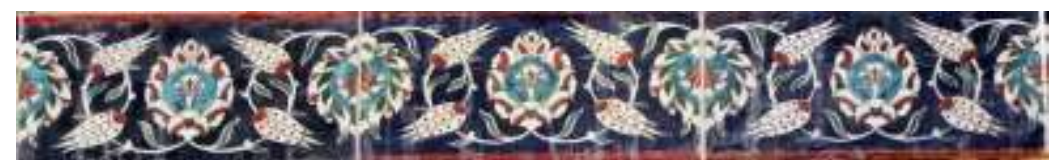



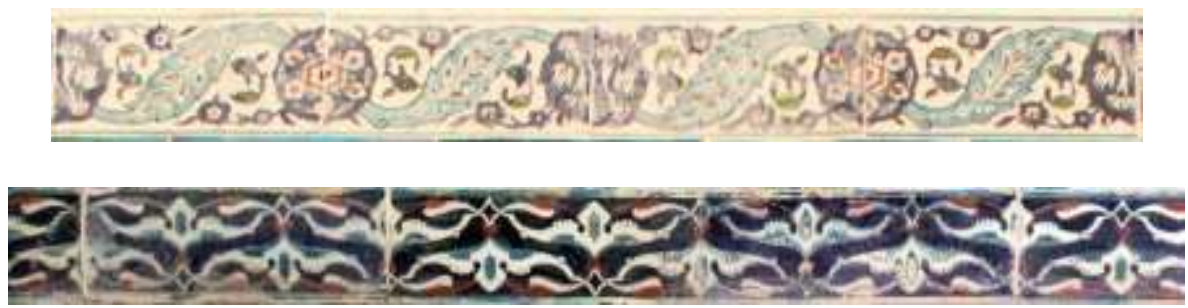

36-38: İmitasyon bordür çinileri.

Hazine-i kütüb'de çini ile bezeli alanlardan biri de pencerelerin üçgen köşelikleridir. E Duvarında yer alan üç adet pencere köşeliğinde birbirine eş ve yarı stilize gül, karanfil, lale ve ayn1 safâ çiçekleri ile oluşturulmuş serbest bir kompozisyon yer almaktadır. Bu cephenin karşısında $\mathrm{C}$ Duvarının üç penceresinden ortadaki, diğerlerinden farklı olarak stilize bulut motifleri ile bezelidir. Üçgen bezeme sahasının iki yanında yarım motifler kullanılmıştır. Böylece kompozisyon iki yöne istenildiği kadar çoğaltılabilir. (Fotoğraf 39) Aynı duvarda yer alan Pencere 3'de yarı stilize zambak ve mine çiçeği ile; Pencere 1'de ise karanfil, zambak ve lalelerle serbest kompozisyonlar görülür. D Duvarının E ile kesişen köşesindeki tek penceresinde de köşelikler yine yarı stilize üslûpta gül, lale, ayn-1 safâ ve peygamber çiçeği ile serbest bir tarzda bezenmiştir. 16. yüzyıla tarihlenen pencere köşeliklerinde kobalt mavi, mercan kırmızı ve turkuvaz renkler hakimdir.

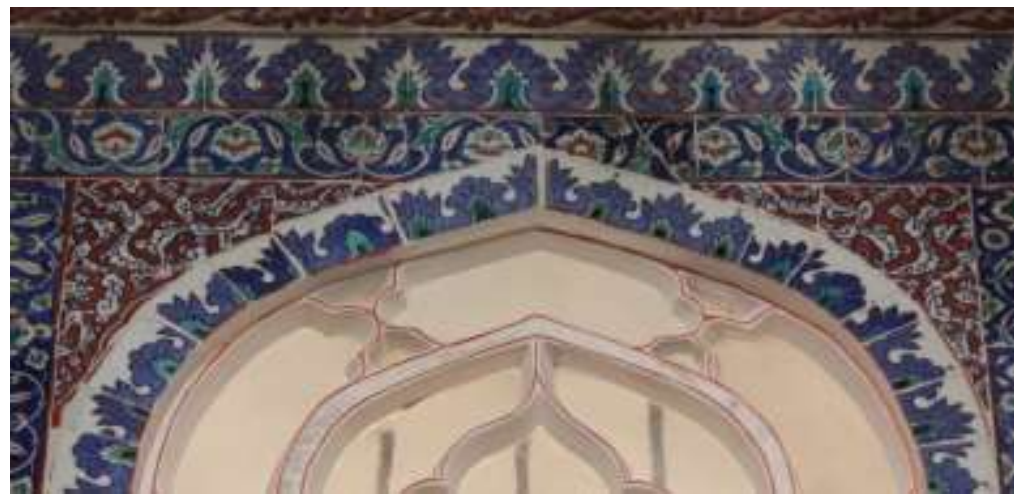

39: Hazine-i kütüb C Duvarı 2 numaralı penceresinin çinili köşelikleri.

Hazine-i kütüb'ün E ve D Duvarlarında alt sırada, yarı stilize karanfil ve yarı stilize lale ve karanfil motifleri ile simetrik olarak bezeli iki çeşit taklit süpürgelik çinisi kullanılmıştır. (Fotoğraf 40)

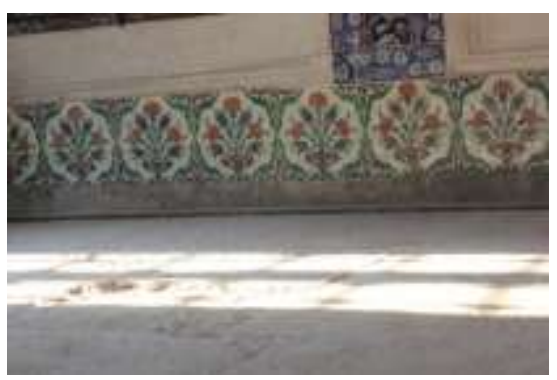

40: Hazine- kütüb E Duvarlarında yer alan imitasyon süpürgelik çinileri.

\section{Değerlendirme ve Sonuç}

Sultan I. Mahmud (sal.1730-1754) zamanında 1739 senesinde Ayasofya bünyesine eklenen Kütüphane, Okuma Odası ve Hazine-i kütüb ile bu iki bölümü birbirine bağlayan L biçiminde bir 
koridordan oluşmaktadır. Kütüphane birimlerinin tüm duvarlarında görülen çini kaplamalar yapıyla yaşıt olmayıp daha erken veya geç tarihlerde üretilmiş, farklı zamanlarda kütüphane duvarlarına yerleştirilmiştir. Bu çiniler arasında çoğunluğu 16. yüzyıl çok renkli sıraltı tekniğinde İznik çinileri oluşturmaktadır. Akar'ın ifadesiyle, padişahın emri ile sarayın çini hazinesinden buraya aktarılmış olan çini kaplamalardan bir kısmı günümüze ulaşmamıştır. Konservasyon Merkez ve Bölge Laboratuarı Müdürlüğü tarafından yapılan, "Ayasofya Müzesi I. Mahmud Kütüphanesi Eski Onarımlar Sırasında Yerinden Alınarak Orijinal Çinilerin Yerine Takılan Imitasyon Çini ve Fayansların Tespit Projesi"ne göre 1882-1896 onarımlarında asıllarının yerine yerleștirilen servili panoların arka yüzeylerinde Fransa'da üretim yapan Choisleroi Seine atölyesinin ismi basılıdır. Kütüphanenin tüm bölümlerinde asıllarının yerlerini almış olan taklit çiniler arasında servili panolardan başka bordür ve süpürgelik çinileri ile ulama karolar da bulunur. Kütüphane'de İznik'den başka, III. Ahmed Dönemi'nde (sal.1703-1730) İstanbul Tekfur Sarayı'nda üretilmiş olan çok renkli sıraltı tekniğinde çiniler kullanılmıştır.

$\mathrm{Bu}$ çalışmada tasarım esaslarına göre yapılan tasnifte Kütüphane'nin çinileri şu başlıklar altında değerlendirilmiştir: 1. Dikdörtgen bir saha içerisinde ve bulundukları yer için özel olarak tasarlanmış olan, desenin bir motif ile başlayıp yukarıya doğru gelişerek tamamlandığı panolar. 2 . Bir veya dört karoda tasarlanarak iki kenarından veya dört tarafindan taşımak veya katlamak suretiyle istenildiği kadar çoğaltılmaya elverişli ulama çiniler. 3. Panolar ile ulama çinilerin ve pencereler ile dolap nişlerinin etrafını çevreleyen ve iki yandan istenildiği kadar çoğaltılabilen bordürler. 4. Pencerelerin üçgen köşelerini bezeyen köşe dolgular. 5. Mekan duvarlarının en alt sırasında kullanılan ve iki yandan biteviye çoğaltılmaya elverişli süpürgelik çinileri. Bunlardan başka, çini malzeme üzerine aktarılmış olan yazı levhaları ile yazı kuşakları.

Ayasofya I. Mahmud Kütüphanesi'nde ikisi koridorda, biri Hazine-i kütüb'de olmak üzere toplam üç adet 16. yüzyıl İznik üretimi çini pano yer almaktadır. Bunlar simetrik olarak tasarlanmış, yarı stilize ve hatayi üslûbundaki motiflerle bezeli, devrinin karakteristik renkleri olan kobalt mavi, mercan kırmızısı ile turkuvazın hakim olduğu panolardır. 16. ve 17. yüzyılın en sevilen üslûplarının başında gelen bahar ağacı ve yarı stilize çiçek üslûbu, Osmanlılar'da dini ve sivil yapılarda sıkça kullanılmıştır. Kompozisyonlar zeminden çıkan bahar ağacı veya bahar dalları ile yukarıya doğru büyüklü küçüklü, yalınkat ve katmerli çiçeklerle bezeli olduğu halde ilerler. Desen sahalarının alt kısımlarında çeşitli yarı stilize çiçekler kullanılır. Bahar ağaçlı panolarda şemse ve vazo motiflerinin kullanımına da sıkça rastlanmaktadır. İleri derecede stilizasyonun hakim olduğu panolarda ağacın türü ayırt edilemez. İstanbul'da Hürrem Sultan Türbesi (1558), Topkapı Sarayı Sünnet Odası dış cephesi (16. yüzyıl ikinci yarısı), Topkapı Sarayı Altın Yol (16. yüzyıl ikinci yarısı), Tahtakale Rüstem Paşa Camii son cemaat yeri (1563), Edirne Selimiye Camii minberi, kemer köşelikleri ve hünkâr mahfili (1574) 16. yüzyılın en güzel bahar dallı panolarının bulunduğu yerlerden yalnızca birkaçıdır. Topkapı Sarayı Harem Dairesi'nde Şadırvanlı Sofa, Kara Ağalar Taşlığı, Şehzâdegân Mektebi, Vâlide Sultan Yatak Odası bahar ağacı motifinin şemseli ve vazolu örneklerinin bulunduğu 17. yüzyılın ikinci yarısına tarihlenen İznik çinileri ile bezenmiştir. (Dumlupınar, 2015: 130,148,166,186,236). Ayasofya I. Mahmud Kütüphanesi'nin koridorunda yer alan bahar ağaçlı pano, Kütüphane'nin en dikkati çeken eserlerindendir. Zeminden çıkan bahar ağacının dalları yukarı doğru yayılarak tamamlanırken, ağaç diplerinde yarı stilize çiçekler yaprak kümelerine eşlik eder. Panoda şemse ve vazo gibi motifler yer almaz. Köşe dolgularında ise çoğunlukla tercih edildiği üzere burada da rumi motifleri kullanılmıştır. (Fotoğraf 15,16,19) Koridorda yer alan diğer pano ise hatayi üsluplu, yukarıda bir kemer, köşebentler ve etrafinda bordür ile pano hüviyeti kazandırılmış, yan kenarlarına yerleştirilen yarım motifler sayesinde iki tarafa doğru çoğaltılmaya imkan sağlayan ulama bir panodur. (Fotoğraf 17,18) Panonun bir benzeri Edirne Selimiye Camii (1574) hünkâr mahfilinde, mihrabın iki yanında kullanılmıştır. Bu tarzda, yukarıya doğru devam eden ritmik hareketin iri dilimli kıvrak yapraklarla vurgulandığı kompozisyonlar 17. yüzyılda sıklıkla tercih edilir olmuştur. Topkapı Sarayı Harem Dairesi Çifte Kasırlar'ın ulama panoları buna örnek gösterilebilir. (Dumlupınar, 2015: 396,503) Karakteristik bir 
16. yüzyıl panosu ise Hazine-i kütüb'de yer alan hatayi üslüplu, simetrik panodur. Aşağıda rumi bezeli harikulade vazosu, orta bölümde yapraklarla meydana getirilen göbek kısmı ve detaylı motifleri mensubu olduğu döneme göz kırpar. (Fotoğraf 22,23) Panonun bir benzeri Eyüp Sultan Türbesi'nde yer almaktadır. (Turan Bakır,1999: 247.) Hazine-i kütüb girişinde yer alan karşılıklı iki adet servili pano ise orijinallerinin yerini alan taklit çinilerdir. II. Abdülhamid (sal.1876-1909) döneminde Albert Sorlin-Dorigny tarafindan 1882-1896 yılları arasında I. Mahmud Kütüphanesi ile birlikte Ayasofya Türbeleri'nde de gerçekleştirilen restorasyonda yerlerinden sökülerek tamir edilmek bahanesiyle Fransa'ya gönderilen çinilerin yerine asılları değil, ne yazık ki taklit Fransız fayansları getirilerek monte edilmiştir. (Çini Koruma Onarımı Uygulama Raporu, 2012: 1-3.) Servi ağacı ve arka planda asma dalları ile üzüm salkımlarının betimlendiği panolar 16. ve 17. yüzyılın dini ve sivil yapılarında sıkça tercih edilmiştir. Kompozisyonlarda tek, ikili veya üçlü servi ağaçlarına kimi kez bahar dalları eşlik etmektedir.

Kütüphane'nin tüm bölümlerinde kullanılmış ulama çiniler arasında 16. yüzyıla tarihlenenler, 16. yüzyıl Osmanlı yapılarında kullanılmış olan çinilerdir. Bunlar arasında bir çini karonun yarı alanı içinde tasarlanarak çoğaltılan, tek karoda tasarlanıp dört yönde çoğaltılabilen veya dört karoda tasarlanarak her yönde çoğaltılabilen ulama çiniler yer alır. Duvarlar, kemer yüzeyleri, tavanlar, filayakları gibi geniş alanların bezemesinde kullanılan ulama çiniler tasarlandığı saha içerisinde, kenarlarda kullanılan yarım motifler sayesinde biteviye çoğaltılmaya imkan sağlar. Koridor ve Hazine- kütübde kullanılmış olan şemseli ulama çiniler ( Fotoğraf 26) ile Topkapı Sarayı Hırka-i Saadet Dairesi Şadırvanlı Sofa, II. Selim Türbesi, Takkeci Camii, Eyüp Sultan Türbesi harimi, Beylerbeyi Camii ile Gülbenkyan Müzesi’nde karşılaşılır. Tek karoda tasarlanarak her yöne çoğaltılabilen, içi yarı stilize çiçeklerle veya rumilerle bezeli, şemseli kompozisyonlar 17. yüzyılda da sıkça kullanılmıştır. Koridor ve Hazine-i kütübün bir diğer benzer tasarım şemasına sahip çinisi ise yine tek karoda tasarlanarak her yöne çoğaltılabilen dairevî şemseli örnektir. (Fotoğraf 27) Mesih Mehmed Paşa Camii (1586) mihrabında kullanılmış olan çiniler ile Sultan Ahmed Camii ve Gülbekyan'da da karşılaş1lır. (Turan Bakır,1999: 48) Kütüphane'de 16. yüzyıl ulama çinilerinden başka Okuma Odası, Koridor ve Hazine-i kütüb'de orijinallerinin yerlerini dolduran imitasyon ulama çiniler bulunur. Bu çiniler tanıdık desenlere sahip olmalarına rağmen sırsız yüzeyleri ile orijinal çinilerden kolaylıkla ayırt olunurlar. Kütüphane'nin diğer ulama çinileri ise Tekfur Sarayı üretimidir. III. Ahmed döneminde İstanbul'da Tekfur Sarayı'nda kurulan çini imalathanesinin çinileri soluk zemin renkleri ve uçları sivri çizilmiş motifleri ile tanınır. Başta Hekimoğlu Ali Paşa Camii (1735) olmak üzere pek çok yapıda kullanılmış olan Tekfur Sarayı çinileri arasında en meşhur olanı belki de benek ve kaplan çizgisi motiflerinin kullanıldığı ulama çinilerdir. Topkapı Sarayı Haremi Çeşmeli Sofa'da kuzeybatı duvarında (Dumlupinar, 2015: 312) ve Sultanahmed III. Ahmed Çeşmesi (1728) saçak altında tek sıra halinde, Topkapı Sarayı Kutsal Emanetler Dairesi Has Oda'da (Ilgaz, 2015: 14) kullanılmış olan çinilerin Hekimoğlu Camii mihrap duvarında yer alan bir başka versiyonunda kaplan çizgisi motifine arka planda yarı stilize çiçekler eşlik etmektedir. Okuma Odası'nın D Duvarı ile Koridor ve Hazine-i kütüb'ün çeşitli duvarlarında gerektiği yerlerde kullanılmış olan benek motifli çinilerden başka pencere içleri ve kitap nişlerinde de farklı desenlerde Tekfur Sarayı çinisi kullanılmıştır. Bunlar sümbül demeti, çiçek demeti ve penç motifli çinilerdir. Soluk mavi zemin üzerinde kobalt mavi, koyu kırmızı ile petrol yeşili renklerinin hakim olduğu çinilerin yüzeyinde hafif tahribatlar görülür.

Panoların ve aynı desendeki ulama çinilerin, pencerelerin ve kitap nişlerinin etrafında dolaşarak onları sınırlayan ve bir nevi çerçeve vazifesi gören bordür çinileri iki yandan biteviye çoğaltılmaya elverişli olmakla ulama çiniler ile benzeşirler. Hazine-i kütüb'de 16. yüzyıl bordür çinileri arasında üzüm salkımlı, asma yapraklı olanı dikkati çekmektedir. Kobalt mavi zemin üzerinde motiflerin beyaz bırakıldığı çinilerin benzerleri Topkapı Sarayı Mukaddes Emanetler Dairesi Has Oda'da ve Beylerbeyi Camii'nde bulunur. Bordürün parçalarına dünya müzelerinde de rastlanmaktadır. (Ilgaz, 2015: 16,17) Kütüphane'nin bütün bölümlerinde kullanılmış olan Tekfur 
Sarayı üretimi bordür, Topkapı Sarayı Haremi Çeşme Sofa'da ve Hekimoğlu Ali Paşa Camii mihrap duvarında da görülür. Okuma Odası'nda Kelime-i tevhid levhasının etrafında kullanılmış olan 18. yüzyıl Kütahya mamülü olan mavi beyaz bordürün benzeri ise Topkapı Sarayı Sünnet Odası'da kullanılmıştır. (Yeşilyurt Koçer, 2014: 217)

Hazine-i kütüb'de üst kat pencerelerin üçgen köşelikleri yarı stilize çiçeklerle serbest olarak bezenmiştir. Başta gül, lale ve karanfil olmak üzere çeşitli çiçeklerin kullanıldığ köşelikler 16. yüzyılın klasik renklerini taşırlar. C Duvarında yer alan 2 numaralı pencerede ise diğerlerinden farklı olarak bulut motifleri kullanılmıştır. İki kenarda kullanılan yarım motifler sayesinde çoğaltılma imkanı olan köşeliklerde motifler, mercan kırmızı zemin üzerinde beyaz bırakılmıştır.

Kütüphane'nin en özenilmiş odası olan Hazine-i kütüb'ün iki duvarında yarı stilize çiçekli ve simetrik olarak bezenmiş 16. yüzyıl taklidi süpürgelik çinileri kullanılmıştır. D Duvarında kullanılan süpürgelik çinilerin orijinalleri Takkeci Camii, II. Selim Türbesi ve Gülbenkyan Müzesi'nde yer alır. (Turan Bakır,1999: 148)

Her devirde dini ve sivil yapıların iç ve dış bölümlerinin bezenmesinde kullanılan çini kitâbeler, aynı zamanda metinlerinin içerikleri ile de ziyaretçilere yapının banisinin mesajını iletirler. Özellikle 17. yüzyılda, kobalt mavi zemin üzerinde beyaz bırakılmış celi sülüs yazılar, kimi kez yazı boşluklarını dolduran motifler ile daha sık kullanılır olmuştur. Eminönü'nde Yeni Vâlide Külliyesi'nin (1665) cami, türbe ve kasırda kullanılmış olan çini kitabeleri döneminin zevkini yansıtması bakımından dikkati çekmektedir. Yapıların iç ve dış kısımlarında görülen çini kitabeler, yazı şeridi olarak veya duvarların belirli yerlerinde yahut pencere alınlıklarında levhalar halinde kullanılmıştır. Ayasofya Kütüphanesi'nde Okuma Odas1 ile Koridor bölümlerinde çini kitâbeler ile karşılaşılır. Hazine-i kütüb ise kitâbe bakımından oldukça zengin olmakla birlikte burada çini malzeme üzerinde yazıya rastlanmaz. Okuma Odası'nda levha ve Koridor bölümünde yazı kuşağı olarak kullanılan Arapça kitabelerde âyet-i kerîme, esma-i hüsnâ ve dualar yazılıdır. Kitabelerde imza ve tarih bulunmamaktadır.

Sultan I. Mahmud zamanında Ayasofya'ya eklenen yapılardan biri olan Kütüphane, esasında mabedin içerisinde, güney nefin üzerindeki iki payanda arasında yer almaktadır. Yapıldığı devirde toplumun her kesimi tarafından rağbet gören Kütüphane, bu makaleye, kendisi için yazılan eski bir destanda (Dağl1, 1948 :60; Ünsal 2011: 205; Aynur, 2014: 686) geçtiği üzere cümle duvarlarını bezeyen kâşîleri dolayısıyla konu olmuştur. Kütüphane, 16. yüzyıl çok renkli sıraltı tekniğinde İznik çinileri esas olmak üzere, sonraki dönemlere ait çiniler ve restorasyonlarda asıllarının yerlerini alan taklit çiniler ile zengin bir koleksiyona sahiptir. Kütüphane'nin inşa tarihi, İznik'te çini üretiminin olmadığı, İstanbul'da yeniden teşebbüs edilen çini imalatından istenilen sonucun alınamadığı bir döneme denk düşmektedir. $\mathrm{Bu}$ sebeple eldeki malzemeler değerlendirilerek Kütüphane'ye en uygun şekilde bir düzenleme yapılmıştır. Farklı devir çinilerinin bir arada kullanıldığı diğer Osmanlı yapılarında da bir sebeple dökülen/ çalınan/tahrip olan çinilerin yerleri, restorasyonlarda, eldeki çinilerle veya kalemişleri ile tamamlanmakta kimi kez ise sıvanarak boş bırakılmaktadır.

\section{Kaynakça}

Akar, A.(1971). Ayasofya'da Bulunan Türk Eserleri ve Süslemelerine Dair Bir Araştırma. Vakıflar Dergisi, IX (1971), 277-290.

Akgündüz, A. Öztürk S. ve Baş, Y. (2005). Üç Devirde Bir Mabed Ayasofya. Osmanlı Araştırmaları Vakfi, 424-441.

Aynur, H. (2104). I. Mahmud'un Kütüphaneleri ve Tarih Manzumeleri. İsmail E. Erünsal'a Armağan, 2. Cilt, Ülke Kitapları, 681-735. 
Berk, S. (2006). Ayasofya Kitâbe ve Hatları. Vakıflar Dergisi Özel Sayısı, 66-67.

Can, S. ve Yıldız Altunbaş, E. (2015). Ayasofya I. Mahmud Kütüphanesi ve Geçirdiği Onarımlar. Atatürk Üniversitesi Güzel Sanatlar Enstitüsü Dergisi, 35, 188-222.

Dağl1, M.Y. (1948) İstanbul Mahalle Bekçilerinin Destan ve Mani Katarları. Türk Neşriyat Yurdu, 60 .

Demiriz, Y. (1980). Türk Sanatında Bahar Açmış Meyve Ağacı Motifi. Birinci Milli Türkoloji Kongresi Tebliğler, Kervan Yayınları, 347-400.

Demiriz, Y.(2002). Osmanlı Çini Sanatı. Türkler, XII, 350-357.

Diker, H.F. (2010) Belgeler Işı̆̆ı̆nda Ayasofya'nın Geçirdiği Onarımlar. Mimar Sinan Üniversitesi Sosyal Bilimler Enstitüsü, Yayınlanmamış Doktora Tezi.

Dumlupınar, F.Z. (2015) Topkapı Sarayı Harem Dairesi 17. Yüzyıl Çini Pano Tasarımları. Marmara Üniversitesi Sosyal Bilimler Enstitüsü, Yayınlanmamış Doktora Tezi.

Elmalı, H. ve Durmuş. İ. (2000). İbnü'n-Nahvî. DİA, XXI, 163-164.

Erünsal, İ.(1991). Ayasofya Kütüphanesi. DİA, IV, 212-213.

Eyice, S. (1991). Ayasofya. DIA, IV, 206-210.

Eyice, S.(1991). Ayasofya Kütüphanesi: Mimârî. DIA, IV, 213-214.

Kültür ve Turizm Bakanlığı Kültür Varlıkları ve Müzeler Genel Müdürlüğü İstanbul Restorasyon ve Konservasyon Merkez ve Bölge Laboratuarı Müdürlüğü. (Kasım 2012-2013). Ayasofya Müzesi I. Mahmud Kütüphanesi Eski Onarımlar Sirasinda Yerinden Alınarak Orijinal Çinilerin Yerine Takılan Imitasyon Çini ve Fayansların Tespit Projesi.

Kültür ve Turizm Bakanlığg Kültür Varlıkları ve Müzeler Genel Müdürlüğü İstanbul Restorasyon ve Konservasyon Merkez ve Bölge Laboratuarı Müdürlüğü. (Kasım 2012-2013). Ayasofya Müzesi I. Mahmud Kütüphanesi Çini Koruma Onarımı Uygulama Raporu.

Kültür ve Turizm Bakanlığı Kültür Varlıkları ve Müzeler Genel Müdürlüğü İstanbul Restorasyon ve Konservasyon Merkez ve Bölge Laboratuarı Müdürlüğü. (Kasım 2012-2013). Ayasofya Müzesi I. Mahmud Kütüphanesi Çini Koruma Onarımı Projesi.

Ilgaz, N. (2015) İstanbul'a Ait Yapılardaki Kayıp Türk Çinileri. Fatih Sultan Mehmet Vakıf Üniversitesi Güzel Sanatlar Enstitüsü, Yayınlanmamış Yüksek Lisans Tezi.

Malkoç, N. (1956). Ayasofya Kütüphanesi. Türkiye Turing ve Otomobil Kurumu, 11-12.

Malkoç Öztürkmen, N. (1957). İstanbul ve Ankara Kütüphaneleri. Milli Kütüphane Basım ve Ciltevi, 30-33.

Müstakımzâde, S.S.E. (1928). Tuhfe-i Hattatîn. Türk Tarih Encümeni,541.

Necip Asım. (1893). Kitap. Haz. Ali Yıldız (2012). Büyüyen Ay Yayınları.

Öney, G. (1976). Türk Çini Sanatı. Yapı Kredi Kültür Yayınları.

Öz, T. (1940). Çinilerimiz. Güzel Sanatlar Dergisi, Say1 2, 526.

Suyolcuzâde, M.N. (1942). Devhatü'l-Küttâb. Güzel Sanatlar Akademisi,121.

Sönmez, Z. (2008). Tekfur Sarayı Denemesi. Anadolu Toprağının Hazinesi Çini: Osmanlı Dönemi, Kale Grubu Yayınları, 37-43.

Şahin, S. (2009). Değişim Sürecinde Osmanlı Mimarlığı III. Ahmet ve I. Mahmut Dönemi (17031754). İstanbul Teknik Üniversitesi, Yayınlanmamış Doktora Tezi, 113-140. 
Tayla, H.(1986). Ayasofya Kütüphanesi Restorasyonu. Taç Vakfi Dergisi, I, 13-16.

Tursun Bey, Haz. Tulum, M. (1977). Târih-i Ebü'l-Feth. Fetih Cemiyeti Yayınları, 62-63.

Turan Bakır, S. (1999). İznik Çinileri ve Gülbenkyan Koleksiyonu. Kültür Bakanlığı Yayınları.

Turan Bakır, S. (1999). İznik Çinilerinde Ulama Karo Tasarımları. Osmanlı, XI, 220-226.

Turan Bakır, S. (2007). Osmanlı Sanatında Bir Zirve: İznik Çini ve Seramikleri. Anadolu'da Türk Devri Çini ve Seramik Sanatı, Kültür ve Turizm Bakanlığı Yayınları, 279-305.

Ünsal, G. (2011) Ramazanda Söylenen Mânî Fasıllarını İçeren Eserlerin Folklorik Bakımdan Değerlendirilmesi. İstanbul Üniversitesi Sosyal Bilimler Enstitüsü. Yayınlanmamış Yüksek Lisans Tezi.

Yenişehirlioğlu, F. (2007). Tekfur Sarayı Çinileri ve Eyüp Çömlekçiliği. Anadolu'da Türk Devri Çini ve Seramik Sanatı, Kültür ve Turizm Bakanlığı Yayınları, 349-361.

Yeşilyurt Koçer, F. (2014). Topkapı Sarayı Dördüncü Avludaki Yapılarda Kullanılan Çiniler. Atatürk Üniversitesi Sosyal Bilimler Enstitüsü, Yayınlanmamış Doktora Tezi.

Yetkin, Ş. (1993). Çini. DIA, VIII, 329-335. 